\title{
Experimental and Economical Analysis of an Autonomous Renewable Power Supply System for Water Desalination and Electric Generation
}

\author{
A. M. Soliman ${ }^{1,2,3}$, Mohamed A. Sharaf Eldean ${ }^{3} \&$ Imed Miraouia $^{4}$ \\ ${ }^{1}$ Mechanical Engineering Department, College of Engineering, Jouf University, Sakaka, Saudi Arabia \\ ${ }^{2}$ Mechanical Engineering Department, Faculty of Engineering, Suez University, Suez, Egypt \\ ${ }^{3}$ Engineering Scince Department, Faculty of Petroleum and Mining Engineering, Suez University, Suez, Egypt \\ ${ }^{4}$ Research Unit MEER, College of Sciences University of Gafsa, 2100 Gafsa, Tunisia \\ Correspondence: A. M. Soliman, Mechanical Engineering Department, College of Engineering, Jouf University, \\ Sakaka, Saudi Arabia. E-mail: amsoliman@ju.edu.sa
}

Received: August 2, 2019

Accepted: August 21, 2019

Online Published: August 23, 2019

doi:10.5539/mas.v13n9p43

URL: https://doi.org/10.5539/mas.v13n9p43

\begin{abstract}
Solar-Wind systems are growing as a vital option to power different types of membrane desalination processes. It is becoming very important to use renewable power sources because of zero emissions to the environment. In this work, solar photovoltaic (PV) system is used to power on the reverse osmosis (RO) desalination process. Meanwhile, Vertical Wind Turbine (VWT) system has been used as a recovery system during sun absence periods. Moreover, the possibilities to operate a hybrid system of PV-VWT combined with RO system has also investigated. The system is designed to desalinate a low rate of fresh water at a scale capacity of $0.1-1 \mathrm{~m}^{3} / \mathrm{day}$. The system is contained as a mobile unit which can be used to serve rural areas during safari and tourism travels in deserts with some features such as, compactness, stability, and ease of maintenance. The unit product cost (UPC, $\$ / \mathrm{m} 3$ ) is found in the range of $1.51 \$ / \mathrm{m}^{3}$.
\end{abstract}

Keywords: photovoltaic system, vertical wind turbines, reverse osmosis, economic analysis, experimental setup

\section{Introduction}

The Middle East and North Africa regions (MENA) not only have the world's lowest per capita availability of water resources but also the highest rate of reduction in these resources (A. Lamei, 2008). The major cause of the water budget deficit and groundwater depletion in the MENA area are anthropogenic drivers rather than climatic ones. Finally, we conclude that if current hydrologic, climatic and socio-economic trends continue, the nations with the lowest gross domestic product per capita, like Egypt, Yemen and Libya, will undergo the highest water deficit per capita, leading to a significant rise in food prices, potentially resulting in more socio-economic instabilities over the next three decades (Annamaria, 2018). Growing numbers of people in that particular region will face severe freshwater scarcity (A.Lilane, 2019). The desalination of seawater and brackish water has become an increasingly important as well as effective process against the shortage of freshwater resources in the whole world, especially in the Saharan and the MENA regions (H. Nouri, 2019). Fortunately, all MENA countries have an abundant renewable energy potential that enhances the application of solar and/or wind technologies for powering desalination units in order to overcome the water shortage problems.

The production of fresh water using desalination technologies driven by renewable energy systems been thought to be a vital solution to the water scarcity in remote areas characterized by a lack of potable water and conventional energy sources like heat and electricity grid (Nafey AS, 2010). Among different desalination technologies, Reverse Osmosis (RO) is a modern process technology to purify water for a wide range of applications, including semiconductors, food processing, biotechnology, pharmaceuticals, power generation, seawater desalting, and municipal drinking water. Reverse Osmosis, commonly referred to as RO, is a process where you demineralize or deionize water by pushing it under pressure through a semi-permeable Reverse Osmosis Membrane. Osmosis is a naturally occurring phenomenon and one of the most important processes in nature. It is a process where a weaker saline solution will tend to migrate to a strong saline solution. The main feature of RO is that it requires no thermal energy but, rather, mechanical energy in the form of a high-pressure produced by the feed pump. In the last few years, RO seawater desalination technology has gone through a 
remarkable transformation. The capacity of large RO plants has increased significantly. Systems with permeate capacity up to $300,000 \mathrm{~m}^{3} / \mathrm{d}$ are currently being built (Wilf Mark, 2005). At the same time, renewable energy technologies are widely distributed during the past few decades especially with desalination processes. Most of these renewables been focused on solar electric power generation. For instance, Photovoltaic or/and wind energies are considered promising techniques while dealing with such desalinating processes. George Kyriakarakos (George Kyriakarakos, 2017), addressed the variable load energy management system based on Fuzzy Cognitive Maps (FCM) on the reverse osmosis desalination process. In order to assess variable load operation two case studies have been investigated through that simulation. For both case studies, initially a PV-battery system has sized through optimization for a desalination unit operating only at full load. Driss Zejli (Driss Zejli, 2011) studied another renewable application with thermal desalination process. A renewable hybrid system to produce domestic water was presented. It consists of a photovoltaic module, a wind turbine, mechanical vapor compression plant and a storage unit. One of the most important reasons of using RO instead of thermal distillation processes is the reliability and the ease of combining directly with renewable energy resources such as solar and wind energies. Solar and/or wind energies are rightfully deserved to be used by an RO desalination process. Most of solar applications combined with RO are established based on Photovoltaic (PV) and horizontal wind turbine (HWT) technologies.

However, in comparison, thermal energy required is approximately of the range $4-12 \mathrm{kWh} / \mathrm{m}^{3}$ and electrical energy of the range $1.5-4 \mathrm{kWh} / \mathrm{m}^{3}$ (Upeksha Caldera, 2016). Thus, the total energy required is of the range 5.5$16 \mathrm{kWh} / \mathrm{m}^{3}$ (Upeksha Caldera, 2016). The total energy required for membrane processes is of the range 0.5-4 $\mathrm{kWh} / \mathrm{m}^{3}$, so it has lower specific energy consumption than thermal processes (Upeksha Caldera, 2016). Sharaf et al. (Mohamed A. Sharaf, 2013) used REDS software library for the investigation of coupling Photovoltaic electrical power with reverse osmosis desalination plant in order to produce $3500 \mathrm{~m}^{3} / \mathrm{d}$. The unit product cost was around $0.5305 \$ / \mathrm{m}^{3}$ for $1131 \mathrm{kWe}$ power (Mohamed A. Sharaf, 2013). Mohammed Laissaoui et al. (Laissaoui, 2018) studied the operation of large-scale reverse osmosis units in combination with different solar power plants, both, Concentrating Solar Power (CSP) and Photovoltaics (PV). The addressed configurations have been evaluated under variable load conditions. Some systems were also developed for the supply of fresh water to remote areas, and particularly to cover the needs of small villages or communities. Essam Mohamed et al (Essam Sh, 2008) investigated technically and economically a Photovoltaic system powered brackish water reverse osmosis desalination systems. This system was designed to produce an amount of $0.35 \mathrm{~m}^{3} / \mathrm{d}$ with a specific power consumption around $4.6 \mathrm{kWh} / \mathrm{m}^{3}$. The main reason for the water high production cost $\left(15-20 € / \mathrm{m}^{3}\right)$ was the need of solar batteries to achieve a constant pressure and flow rate for the membranes (Essam Sh, 2008).

Helal et al (A.M. Helal, 2008) studied the economic feasibility of driving RO by PV within low specific power consumption. Three alternative configurations of an autonomous PV-RO unit for remote areas in the UAE were investigated. They also work studied the possibility by using a diesel generator for a day off periods. The PV-RO was designed for not more than $20 \mathrm{~m}^{3} /$ day (in $10 \mathrm{hrs}$ ). However, they did not investigate the effect of diesel emissions on the environment. A. Cipollina et al (A. Cipollina, 2014) presented and analyzed the operation of selected renewable energy system desalination unit. Cipollina (A. Cipollina, 2014) work demonstrated a productivity in the range of $1-10 \mathrm{~m}^{3} /$ day. Based on material effect on PV-RO, M. Freire-Gormaly (Gormaly, 2018) presented an experimental investigation of the effect intermittent operation characteristic of renewable powered desalination systems (PV-RO desalination). Gormaly work showed a future work in order to develop robust design algorithms for renewable powered desalination systems. Manolakos et al (Manolakos, 2008) presented some technical characteristics as well as an economic comparison of PV-RO desalination systems. The PV system was consisted of 18 Arco-Solar mono-crystalline PV panels, with total peak power of $846 \mathrm{~W}$. Their system has a capacity of $0.1 \mathrm{~m}^{3} / \mathrm{h}$ and the specific energy recovery of that system has been experimentally found to be in the range of 3.8-6 kWh/m $\mathrm{m}^{3}$. Manolakos et al (Manolakos, 2008) estimated the cost by $7.77 € / \mathrm{m}^{3}$. However, they did not investigate the large-scale production based on the PV power. Ahmed et al (Ahmad, 2002) studied a design of a PV powered small-scale reverse osmosis water desalination system. It was found that the cost of producing $1 \mathrm{~m}^{3}$ of fresh water using the small PV powered RO water desalination systems is 3.73\$ (Manolakos, 2008). Tzen et al (E. Tzen, 1998) studied the design of an autonomous PV-RO system able to cover potable and other water needs of a rural community in Morocco. That study was built based on $0.5 \mathrm{~m} 3 / \mathrm{h}$ powered by $7.5 \mathrm{~kW}$ of high-pressure pump power $\left(\mathrm{SPC}=15 \mathrm{kWh} / \mathrm{m}^{3}\right)(\mathrm{E}$. Tzen, 1998). Another work is provided for wind powered RO. Liu et al. (Liu, 2007) presented a wind-driven reverse osmosis system for aquaculture wastewater treatment. The freshwater from this study (Liu, 2007) can be used as the freshwater supply for fish culture. The economic analysis was not investigated in study of Liu et al (Liu, 2007). Operation of an experimental RO plant connected directly to a wind system without energy storage been studied by Pestana (Ignacio, 2004). The system was built to produce an amount of $3.6 \mathrm{~m}^{3} / \mathrm{h}$ based on $21 \mathrm{~kW}$ of power. Dehmas et al 
(Djamila, 2011) studied the availability of using the wind power for seawater reverse osmosis (SWRO) desalination plant. An energy yield and economic analysis was performed on a hypothetical wind farm consisting of five wind turbines of type Bonus $2 \mathrm{MWe}$.

It was found that wind energy could successfully power a SWRO desalination plant. Lourdes-Garcia-Rodriguez et al. (L. García-Rodríguez, 2001) analyzed the influence of the main parameters of the cost of fresh water: climatic conditions, nominal power of the wind turbine, the salt concentration of seawater or brackish water, design arrangement, operating conditions, plant capacity, cost of RO modules and cost of wind turbines. Romero-Ternero et al. (V. Romero, 2005) quantified the unit cost of fresh water generated from representative wind-powered seawater RO system as well as the exergy efficiency of the process by means of thermo-economy. Moreover, the exergy-economic analysis of wind-driven seawater RO desalination was cost-effective for the representative wind power site with medium plant capacity and the unit cost of freshwater was $76 \mathrm{c} € / \mathrm{m}^{3}$ (Mohee, 2017). Actually, different plants (Wind+RO) capacities are ranged from $4-200 \mathrm{~kW}$ of nominal power for about a range of $12-2500 \mathrm{~m}^{3} /$ day of desalted water.

It is clear from the literature that the coupling with RO, Wind and PV is considered a promising solution. Moreover, there are many advantages of such combination concluded with: (a) direct connection permit for minimum energy loss, (b) ease of maintenance, (c) reliability and sustainability along the day of operation, (d) suitability for medium and low capacities, (e) the unit can also be used to remediate contaminated water from leaching of contaminated industrial soils such as the following literatures (Mohee, 2017). The novelty in this study is centralized around the design and construction of a new mobile unit for the production of $0.1-1 \mathrm{~m}^{3} /$ day of fresh water. Moreover, vertical wind turbine unit is investigated with the companion of PV and RO for the first time. The system is designed to serve during safari tourism journeys and desert travels across Saudi Arabia with some features such as, compactness, stability, and ease of maintenance and suitable for saline well water sources. The developed mobile unit is light in weight and not too heavy to transport. Moreover, it might be used in order to minimize the pollution associated with transporting. In future, the author's intentions is to use this developed mobile unit for contaminated water purification processes. Different capacities of PV-VWT-RO systems are investigated and analyzed under the weather operating conditions of the location of operation (Lat: 29.953894, Lng: 40.197044: Elevation: 745m Jouf University, Saudi Arabia (www.worldweatheronline.com)). This article describes the process configuration for the proposed systems including an investigation of the design limits, the detailed construction of a mobile PV-VWT-RO desalination unit. Cost analysis of the mobile PV-VWT-RO desalination unit is also considered. Finally, an evaluation of how to apply this system for wide-scale adoption is performed. The system was run in a desert location area in Al-Jouf University, Sakaka, Saudi Arabia.

\section{System Description}

\subsection{Expremental Setup}

The mobile system is designed based on the targeting of producing fresh water, which is suitable for rural areas and camping spots. Such goal needs some features such as compactness, mobility, and ease of use. On January $5^{\text {th }}, 2016$, the proposed mobile unit which contacting all facilities is operated at the location of operation. The data has been recorded along two years of operation (2016-2017). The proposed system contains a mobile control room unit (MCR) for system monitoring, photovoltaic panels (up to $3 \mathrm{~m}^{2}$ ), vertical wind turbine unit for auxiliaries and power recovery $(0.3-0.5 \mathrm{kWe})$, Reverse Osmosis (RO) system $\left(0.1-1 \mathrm{~m}^{3} /\right.$ day) for saline water purification unit (range of TDS: 500-5000), solar \& wind chargers, inverter and Batteries, instruments (Wind speed, Pyranometer, Flow meters...). Figure 1 shows a schematic diagram of the proposed process. The expected result would be the development of autonomous RO desalination prototype based on solar PV-powered electrical generation distributed system of about $0.1-0.5 \mathrm{kWe}$, more cost-effective and efficient than other solar power sources such as thermal systems (i.e., with real market possibilities). The system unit will be inserted into the mobile control room. The roof will hold the PV and the wind turbine systems. Reverse Osmosis, batteries, Inverter, computer lab, and air conditioning units will be inside the mobile control room (MCR). RO unit (membranes, valves, pipes, and high-pressure pump) will be inside the mobile Control Room (MCR) in order to prevent it from any unstable environmental conditions.

Inlet feed stream and outlet brine stream will enter and exit the RO unit from the bottom of the MCR respectively. The fresh water product will come out from the rear of the MCR. It is expected to produce an amount of $0.1-1 \mathrm{~m}^{3} /$ day which is suitable for rural and small groups of publics or nomads. The MCR can be easily movable from region to another. Moreover, the PV field can easily be towed up and down while moving the MCR. Meanwhile; the wind turbine can easily be embedded in the MCR unit. Figure 2 shows the photograph of the proposed system at the location of operation. The total system weight is around $120 \mathrm{~kg}$. A schematic 
integration of $\mathrm{PV} / \mathrm{wind} /$ battery hybrid system is shown in Figure 3. The integration of renewable energy resources PV panels and WTs are connected to the charger controller to charge the battery. The output power is directly connected to feed DC loads and is connected to inverter to feed AC loads. Experimental work is achieved by using a simple variable resistive load and measurement devices as listed in Table 1 . The saline water is supplied from two tanks one with salinity of $3000 \mathrm{ppm}$ and the other with salinity of $500 \mathrm{ppm}$. The change in the salinity of feed water was carried out by adding saline water of $500 \mathrm{ppm}$ to the saline water of $3000 \mathrm{ppm}$ with different proportions to obtain feed water with $(500,1000,1500,2000,2500$ and $3000 \mathrm{ppm})$. The pressure range on the pump unit is varying between 13-16bar.

Table 1. Measurement devices that been used for the proposed system.

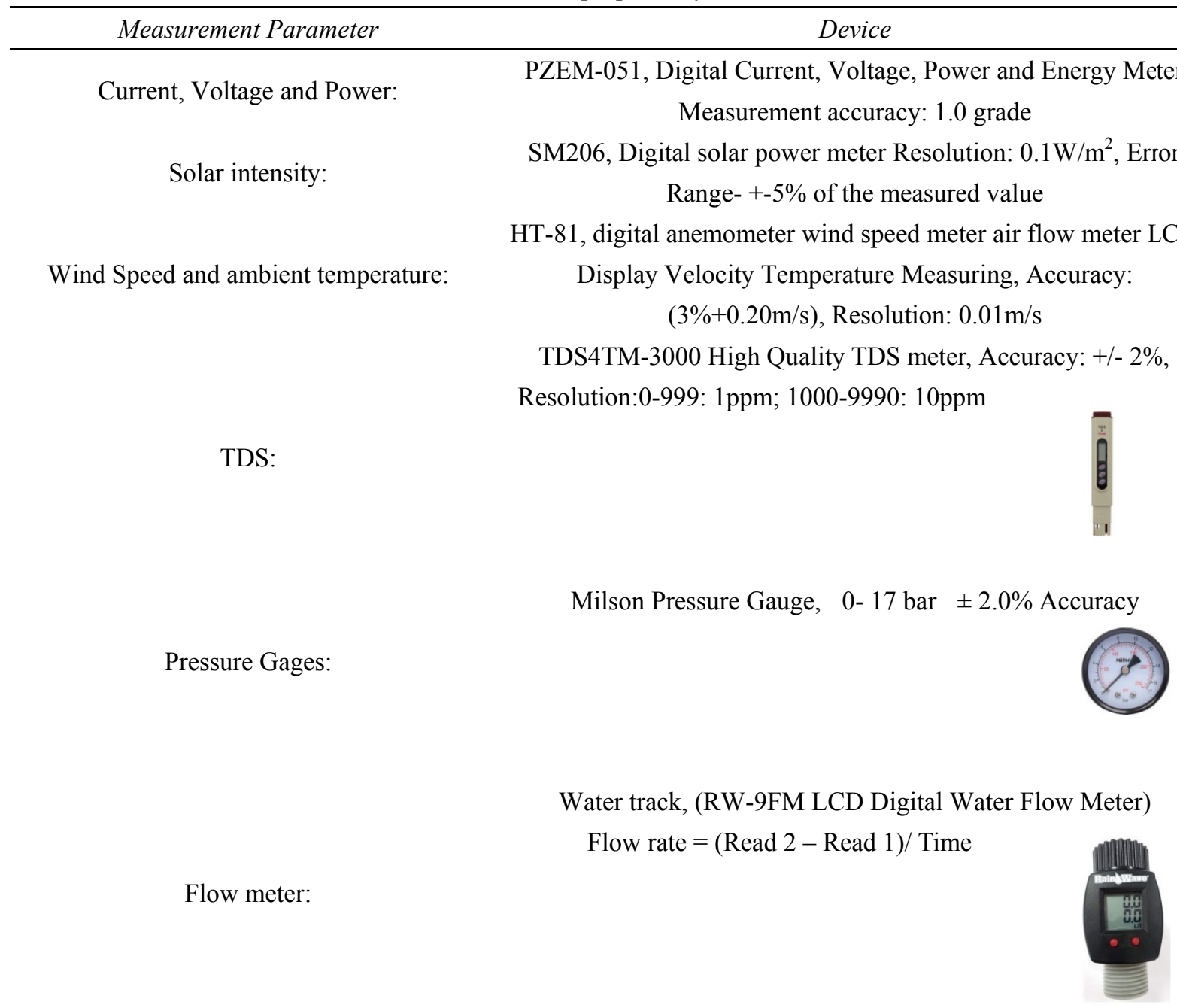

The process system flow diagram:

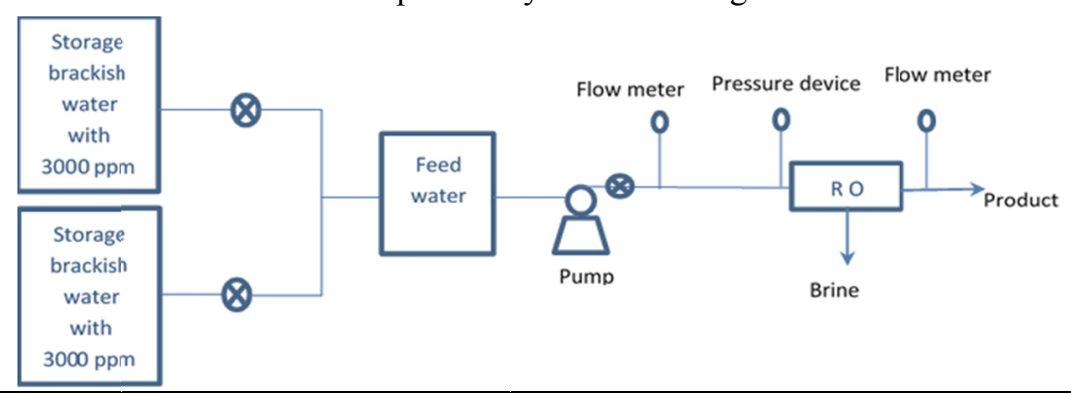




\subsubsection{The RO Part}

The selection of RO unit was decided based on the available power source, salinity range (water type) and needed water production rate. The selected RO is designed to produce an amount of $0.1-1 \mathrm{~m}^{3} /$ day as a production range in this work. The salinity range would be varied between $500-5000 \mathrm{ppm}$. The targeted salinity of the fresh water would be in the range of $15-150 \mathrm{ppm}$. RO can effectively remove non-organic salt, heavy metal ions, and revert saline water to life drinking water. Table 2 shows the design data for the selected RO module.

\subsubsection{The PV Part}

Photovoltaic is required for power input to the system. The PV module is expected to operate directly the RO along 8 hours a day. The system contains PV modules, electric Inverter unit (convert DC to AC), distribution cabinet, structure, and cables. Module power is $300 \mathrm{Watt} /$ module with $36 \mathrm{~V}$. Batteries bank is fixed to the system in order to recover any power shortage during the operating hours. Table 2 shows the design and specification parameters for the PV module.

\subsubsection{The VWT Part}

A vertical-axis wind turbines (VAWT) is a type of wind turbine where the main rotor shaft is set transverse to the wind while the main components are located at the base of the turbine. This arrangement allows the generator and gearbox to be located close to the ground, facilitating service and repair. Vertical wind turbine (VWT) is very important for sun off operation. The main advantage of using VWT is that it does not need any complicated directional control system to catch the wind. It can rotate at any direction according to the vertical fin shape. Table 2 shows the main specifications of the VWT.

\subsubsection{The Batteries \& Inverter Parts}

Batteries of the current PV system are subjected to frequent charging and discharging process. Lead acid battery with deep discharge is used for the PV/VWT. The battery for the PV/VWT is to be designed to meet some characteristics such as low cost, high energy efficiency, long life time, low maintenance, good reliability and less self-discharge. Despite of the storage issues, battery is used in order to supply power at stable voltages by suppressing voltage fluctuations in PV systems and protecting loads from damage. Therefore, a batteries bank is added to run the system during the day off periods. Battery type of $80 \mathrm{~V}$ is operated in the test with lifetime over 5 years of operation. The inverter is used to invert DC current to AC. It is 36 Volt with 10 years lifetime of operation. 


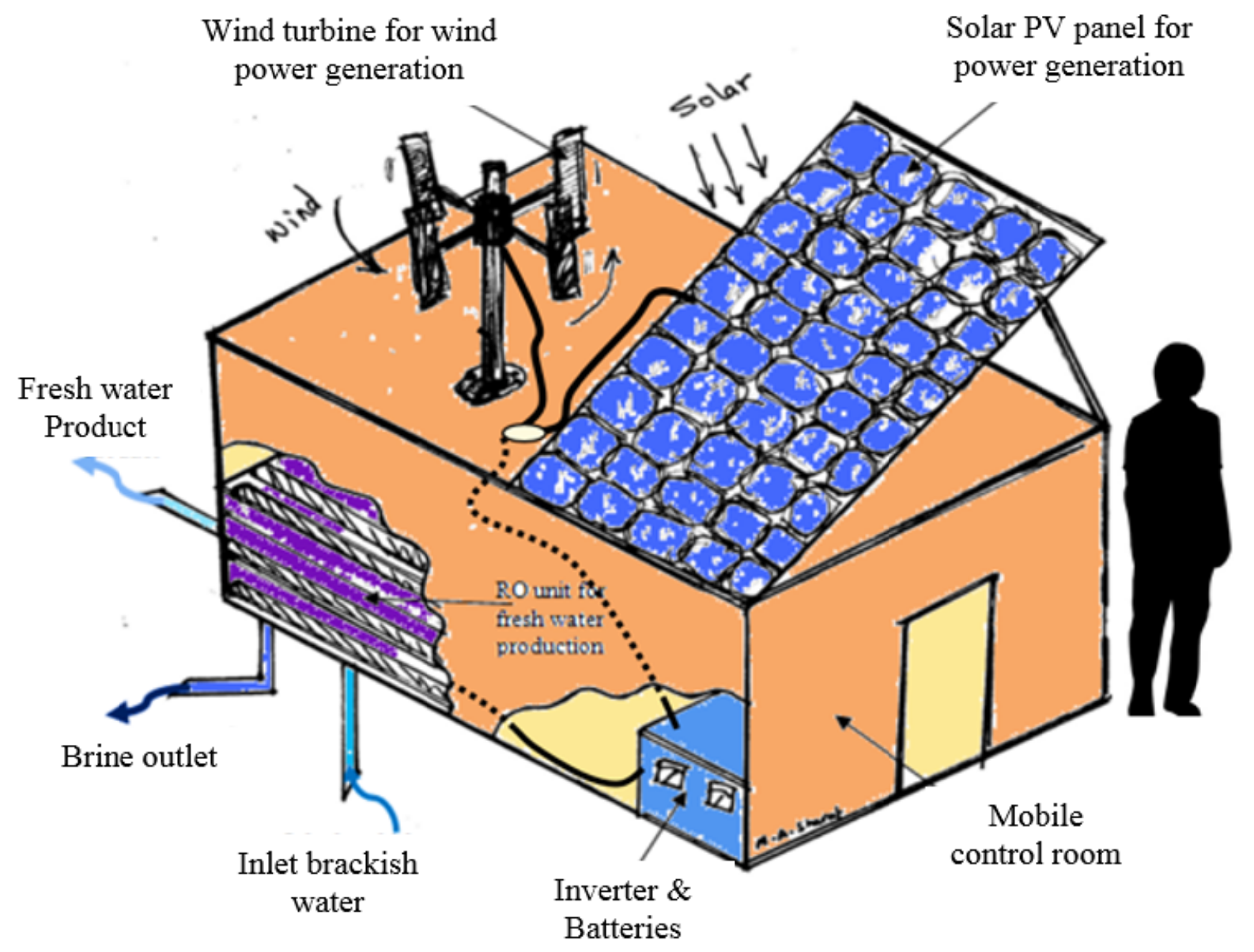

Figure 1. A schematic diagram of the proposed collection of the system units: PV panels, Wind turbine, RO unit, and Inverter \& Batteries.

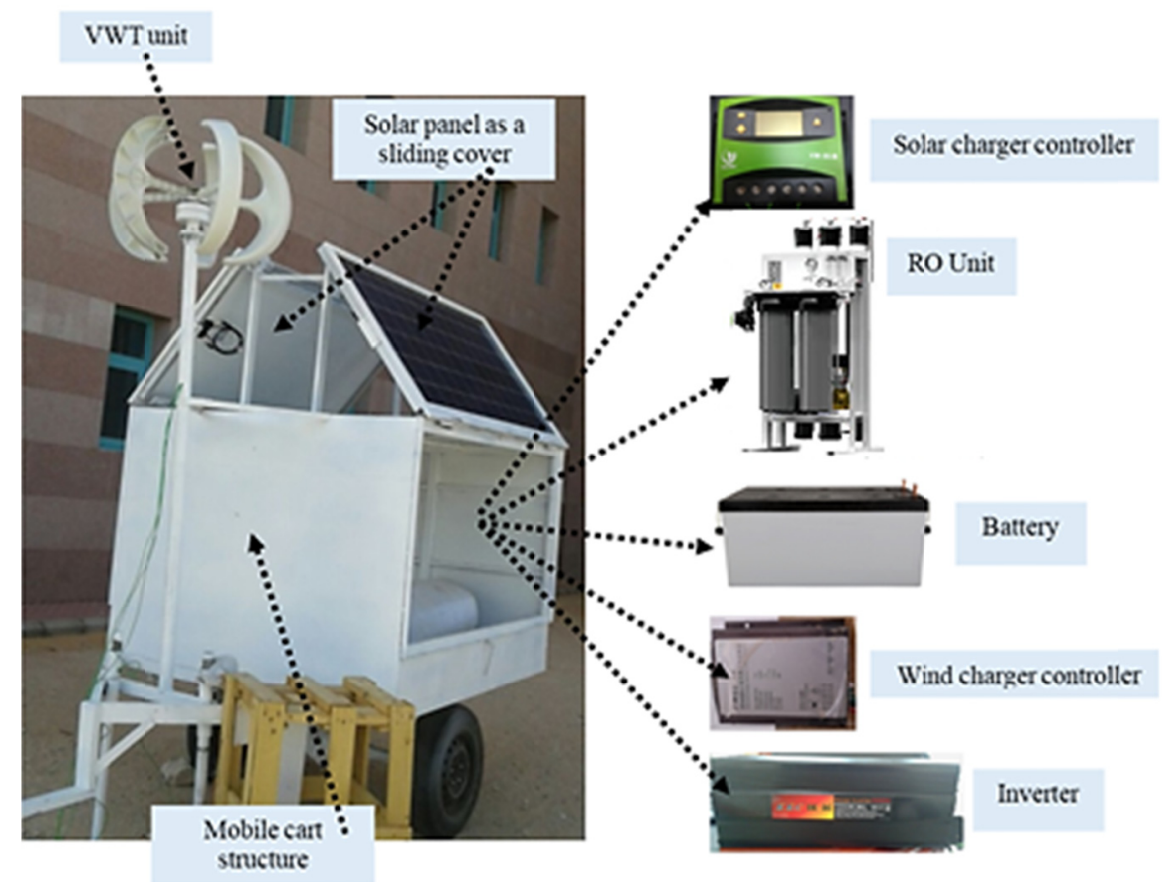

Figure 2. The mobile unit with all devices at the location of operation. 
Table 2. Pilot test unit design and specification parameters for $0.1-1 \mathrm{~m}^{3} /$ day.

\begin{tabular}{|c|c|c|}
\hline \multirow{13}{*}{ RO: } & Productivity $=0.1-1 \mathrm{~m}^{3} /$ day & \\
\hline & Element area $=2 \mathrm{~m}^{2}$ & \\
\hline & No. of elements $=3$ & \\
\hline & No. of pressure vessels $=1$ & \\
\hline & Seawater temperature $=25^{\circ} \mathrm{C}$ & \\
\hline & Pressure $=1-5.5 \mathrm{bar}$ & \\
\hline & Inlet feed salinity $=500-5000 \mathrm{ppm}$ & \\
\hline & High pressure pump efficiency $=79-85 \%$ & \\
\hline & Recovery ratio $=20-45 \%$ & I!1 \\
\hline & Feed water $\mathrm{PH}=5-10$ & \\
\hline & The pre-filter should be changed every $6-9$ months and & \\
\hline & Reverse Osmosis membranes be replaced every 2-3 years & \\
\hline & Life time is 20 years & \\
\hline \multirow{16}{*}{ PV: } & Solar cell type $=$ Polycrystalline & \\
\hline & Module power=300Watt & \\
\hline & Power tolerance $= \pm 5 \%$ & \\
\hline & Inverter $=12 \mathrm{~V} \mathrm{DC}$ input $/ 230 \mathrm{~V}$ AC output & \\
\hline & Open circuit voltage $=45.7 \mathrm{~V}$ & \\
\hline & Short circuit current $=8.55 \mathrm{~A}$ & \\
\hline & Optimum voltage $=37.50 \mathrm{~V}$ & \\
\hline & Optimum current=7.99A & \\
\hline & Max voltage/system $=\mathrm{DC} 600 \mathrm{~V}$ & \\
\hline & Max series fuse rating $=10 \mathrm{~A}$ & \\
\hline & Module efficiency $=15.45 \%$ & \\
\hline & Number of cells/module $=72$ & \\
\hline & Cell size $=156 \mathrm{~mm} \times 156 \mathrm{~mm}$ & \\
\hline & Diodes $=6$ bypass diodes & \\
\hline & Front glass $=4 \mathrm{~mm}$ tempered glass & \\
\hline & Dimensions LxWxD=1956x992x50mm, No. of module $=2$ & \\
\hline \multirow{4}{*}{ Batteries: } & No. of cloudy days/month $=2$ & \\
\hline & Depth of discharge $=80 \%$ & \\
\hline & Battery volt $=80 \mathrm{~V}$ & \\
\hline & Battery efficiency $=75 \%$ & \\
\hline \multirow{7}{*}{ VWT: } & Power $=0.3-0.5 \mathrm{~kW}$ & \\
\hline & Rated wind speed $=11-12 \mathrm{~m} / \mathrm{s}$ & \\
\hline & Rotor diameter $=0.9 \mathrm{~m}$ & \\
\hline & VWT fin length $=0.6 \mathrm{~m}$ & \\
\hline & R.P.M=156 & \\
\hline & Number of VWT $=1$ & \\
\hline & Model: NE300RV, 12V DC & \\
\hline
\end{tabular}




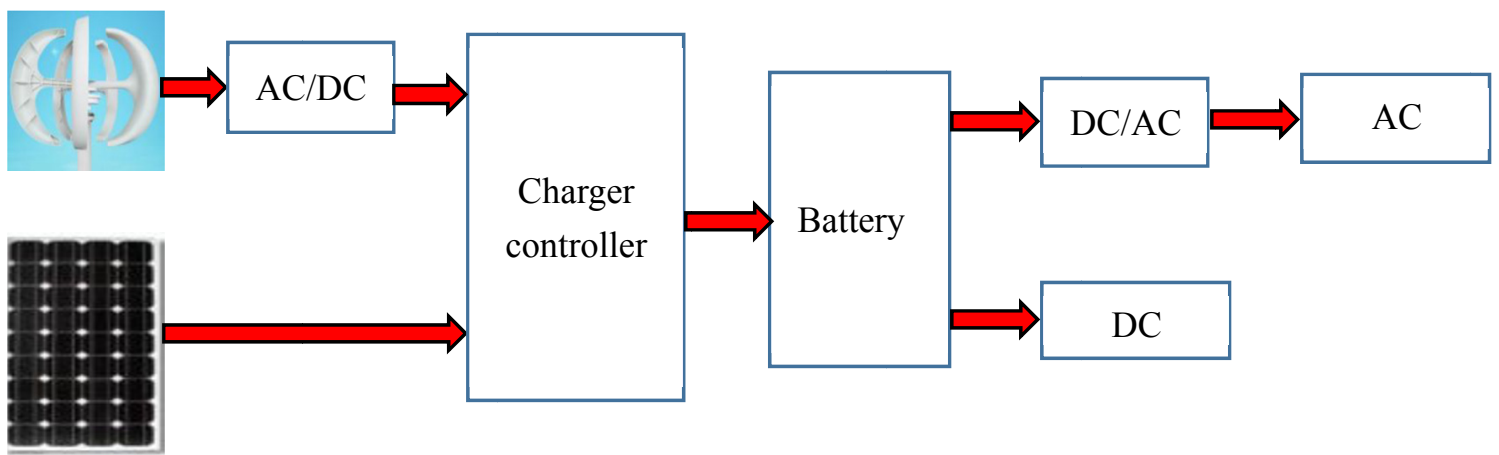

Figure 3. Schematic of a typical photovoltaic (PV)/wind/battery hybrid system

\subsection{The Location of Operation}

The pilot test system is established in Jouf University, Sakaka, Saudi Arabia (Lat: 29.953894, Lng: 40.197044). The location of operation is quite suitable for the model examination. The average total solar radiation is almost $5 \mathrm{kWh} / \mathrm{m}^{2}$, with daily average $590 \mathrm{~W} / \mathrm{m}^{2}$. The average wind speed is around $4 \mathrm{~m} / \mathrm{s}$ along the year. The average ambient temperature is almost $11-35^{\circ} \mathrm{C}$ along the year. Fig's. 4,5 shows the meteorological operating conditions of the location of operation (Ignacio, 2004).

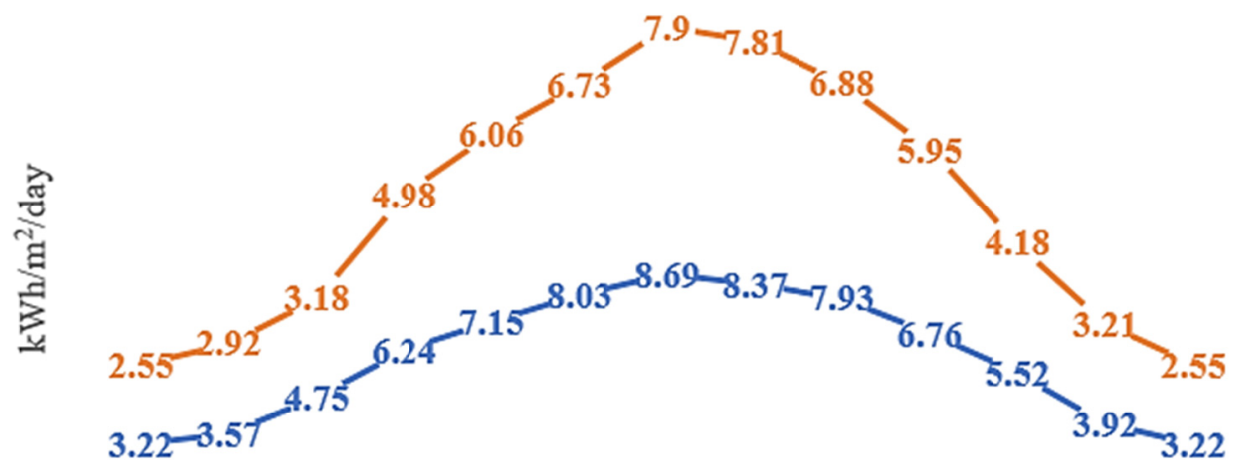

\begin{tabular}{|c|c|c|c|c|c|c|c|c|c|c|c|c|c|}
\hline & Dec & Jan & Feb & Mar & Apr & May & Jun & Jul & $\begin{array}{c}\text { Aug } \\
\text { ust }\end{array}$ & Sep & Oct & Nov & Dec \\
\hline$--\min \mathrm{kWh} / \mathrm{m} 2 /$ day & 2.55 & 2.92 & 3.18 & 4.98 & 6.06 & 6.73 & 7.9 & 7.81 & 6.88 & 5.95 & 4.18 & 3.21 & 2.55 \\
\hline$--\max \mathrm{kWh} / \mathrm{m} 2 /$ day & 3.22 & 3.57 & 4.75 & 6.24 & 7.15 & 8.03 & 8.69 & 8.37 & 7.93 & 6.76 & 5.52 & 3.92 & 3.22 \\
\hline
\end{tabular}

Figure 4. Monthly averaged insolation incident on a horizontal surface $\mathrm{kWh} / \mathrm{m}^{2} / \mathrm{day}$. 


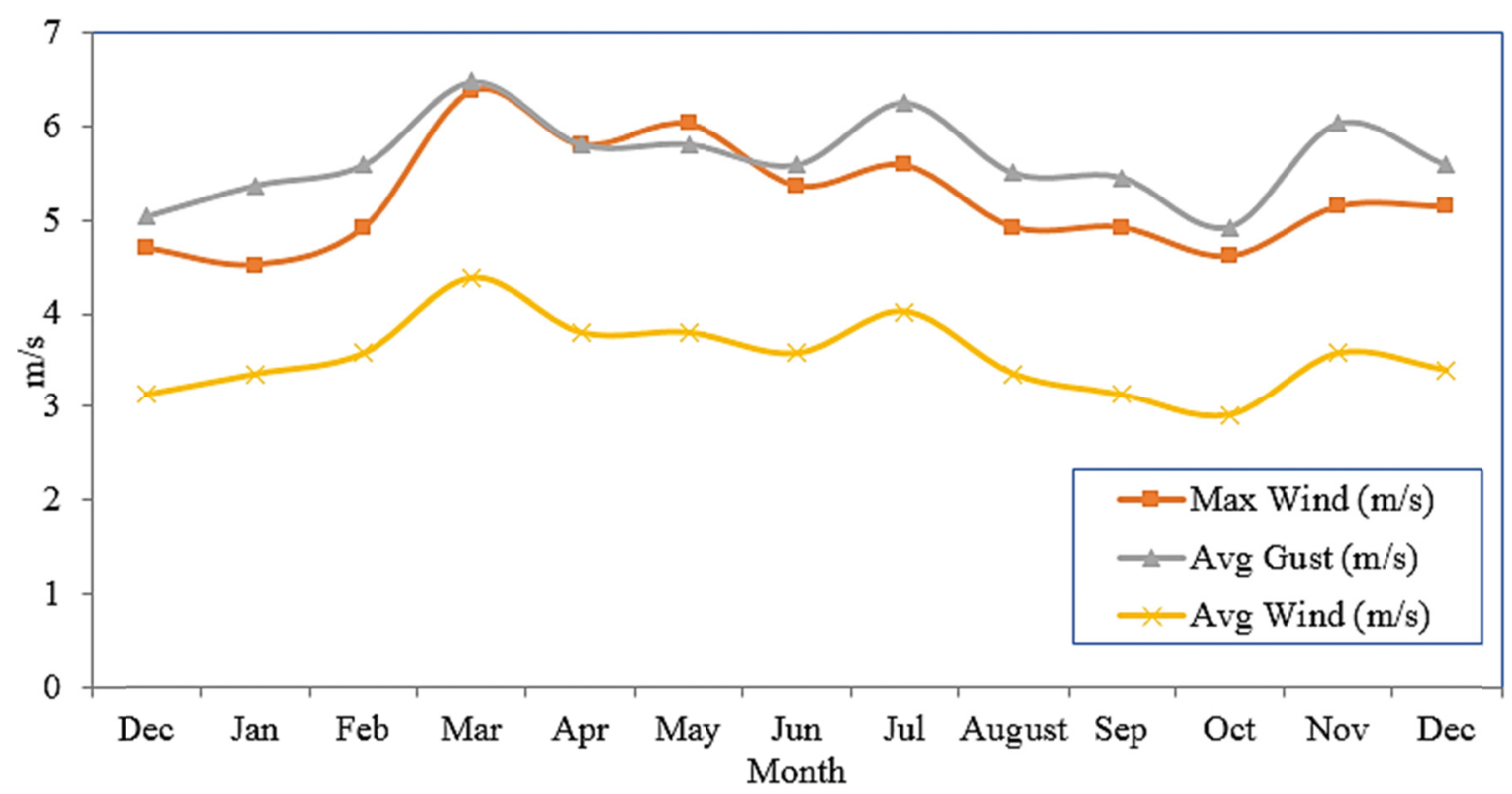

\subsection{System Benefits}

Figure 5. Wind speed distribution at the location of operation [26].

The main objectives of this work is to design and study the performance of an RO desalination unit integrated with an environmentally friendly power supply of PV array. The target is a pilot test unit of $\left(0.1-1 \mathrm{~m}^{3} / \mathrm{d}\right)$ capacity to provide water and power to isolated communities in remote areas with no access to water and power networks. In addition to environmental safety, the unit design should realize certain characteristics such as autonomy, compactness, mobility, suitability to demand, simplicity and energy efficiency. The proposed unit is to present the best possible design combination configuration to also achieve some issues such as compactness and limited needs for ground area, low energy requirements, no need for additional heating components, ease of operation and maintenance, suitability for small capacity of freshwater to meet requirements of small communities, limited intake facilities, no need for chemical pretreatment equipment, so much movable and suitable for desert safari travels across Saudi Arabia, can serve in rural areas and exploratory trips across the desert, and could be used for removing water contaminations and purification processes.

\section{Results and Discussions}

\subsection{Location Analysis}

Data results for the proposed system are collected along one year of operation (2016-2017). However; a typical day on August 2016 is addressed in this study as comprehensive example. All data are recorded relative to the time domain along the example day of operation. As indicated earlier, the pilot test system is established in Jouf University, Sakaka, Saudi Arabia (desert area). Solar radiation data for the proposed location is recorded. Figure 6 shows the daily measurements of the weather conditions for solar intensity and ambient temperature day example that were taken at the $5^{\text {th }}$ of August 2016, from 08:00am to 06:00pm. It is obvious from Figure 6 that the radiation maximum value achieves about $1100-1150 \mathrm{~W} / \mathrm{m}^{2}$ which considered high and optimum for proposed operation. Although, the ambient temperature was relatively high (reducing the PV efficiency) but the system was operated effectively under that operating conditions. 


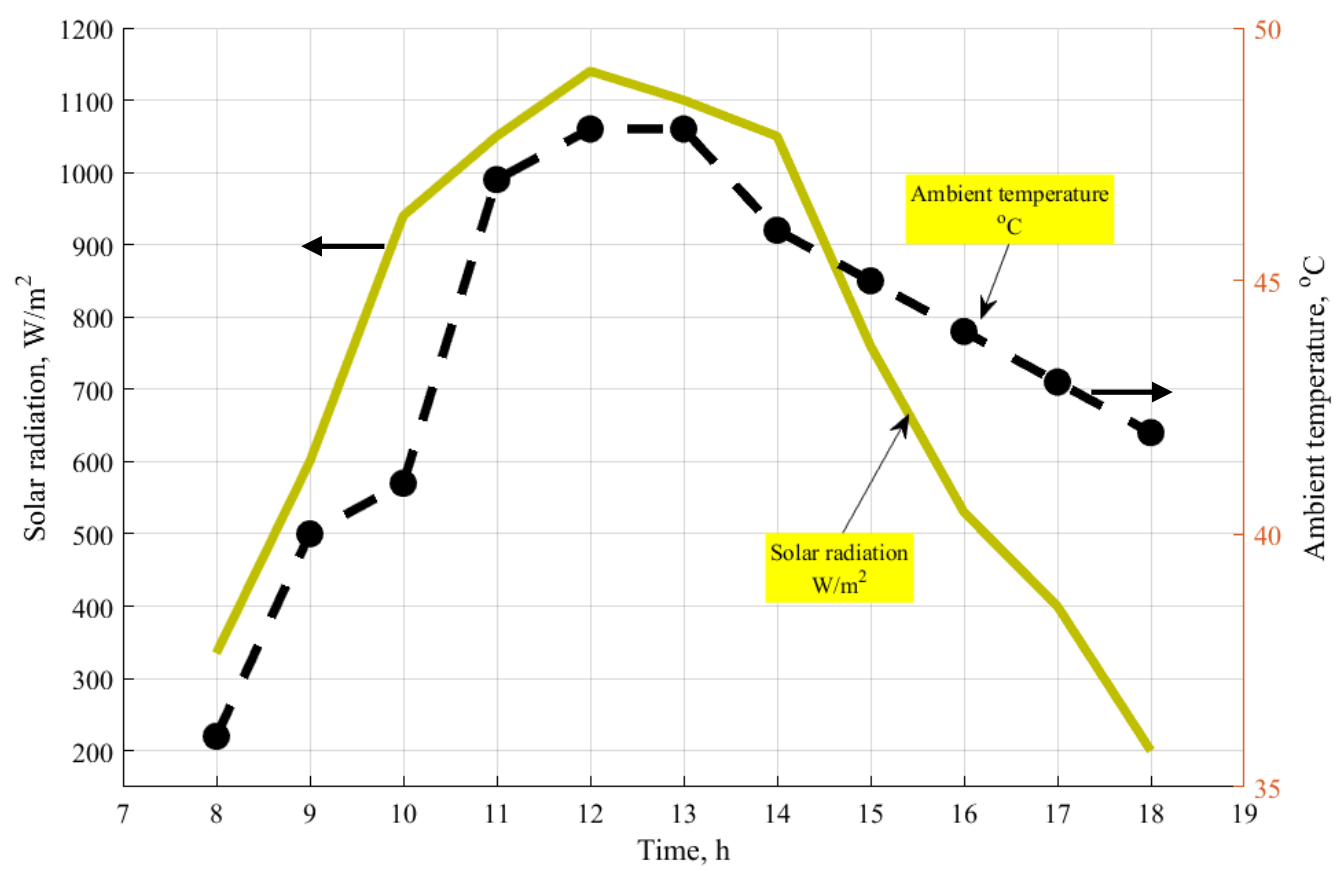

Figure 6. The recorded data of a typical day of August 2016 for solar radiation, $\mathrm{W} / \mathrm{m}^{2}$ and ambient temperature, ${ }^{\circ} \mathrm{C}$.

\subsection{Feed Salinity and Power Effects}

The performance of reverse osmosis unit (RO), under different operating conditions is studied in this part. The performance parameters that been measured are; flow rates, salinity ratios flow rates, specific power consumption, pressure pump power, and exergy streams. The analyses are taken based on the following assumptions of feed salinity is ranged between $500-3000 \mathrm{ppm}$, productivity range was between 0.01 and $0.2 \mathrm{~m}^{3} /$ day, recovery ratio was fixed at $35 \%$ and the pump efficiency was ranges between $79-85 \%$. Figure 7 shows the effect feed salinity on the product and brine salinities. The figure reveals that by increasing the inlet feed salinity, a normal increasing of the product and brine salinities is occurring. For example, at feed salinity equals to $2000 \mathrm{mg} / \mathrm{l}\left(2 \mathrm{~g} / \mathrm{m}^{3}\right)$, the productivity salinity will reach at $35 \mathrm{mg} / 1\left(0.035 \mathrm{~g} / \mathrm{m}^{3}\right)$ with brine salinity at $3100 \mathrm{mg} / \mathrm{l}$. Feed salinity is considered a load on the membrane and the pumping system. Increasing the salt concentration will enlarge the concentration difference between the feed and permeate. It also increases the salt flux due to the higher concentration gradient inside the membrane. Meanwhile, this will lead to the increase of energy consumption due to the load on the pump referring to the pressure difference across the membranes. Its effect is noted on power consumption. Such effect would increase the area of the PV system. That behavior was clearly obvious on Figure 8 with respect to specific power consumption. It is shown by the figure analysis that by increasing the feed salinity (range $=0.5-3 \mathrm{~g} / \mathrm{m}^{3}$ ) with respect, the specific power consumption $\left(\mathrm{SPC}, \mathrm{kWh} / \mathrm{m}^{3}\right.$ ) would increase. Thence, increasing the load on batteries and PV/VWT units. For example, at feed salinity equal to $0.5 \mathrm{~g} / \mathrm{m}^{3}$, and recovery ratio (RR) equal to $30 \%$ the SPC was $1.35 \sim 1.4 \mathrm{kWh} / \mathrm{m}^{3}$. While at feed salinity equal to $3 \mathrm{~g} / \mathrm{m}^{3}$, and $\mathrm{RR}=15 \%$, the SPC is recorded as $4-4.5 \mathrm{Wh} / \mathrm{m}^{3}$. Figure 9 shows the direct effect of feed salinity on feed and brine flow rates. Increasing the salinity contents would increase the mass flow rates of the system, hence, increasing the power load on the PV/VWT unit. It's clear that the designer should put in consideration the salinity of the location of operation putting in mind the load on the PV and the VWT as a recovery unit. Figure 10 shows the effect of power variation on the system productivity, brine blow-down and feed flow rates. Increasing the power rates is quite significant to effect on the system productivity. For instance, at power value of $0.07 \mathrm{~kW}$, the system will produce an amount of $1 \mathrm{~m}^{3} /$ day and will harvest an amount of $3.48 \mathrm{~m}^{3} /$ day of inlet feed. At low rates of power $(0.02 \mathrm{~kW})$, the system productivity will be in the range of $0.5 \sim 0.6 \mathrm{~m}^{3} /$ day and the feed flow rate will be in the range values of $1.6 \sim 1.7 \mathrm{~m}^{3} /$ day. 


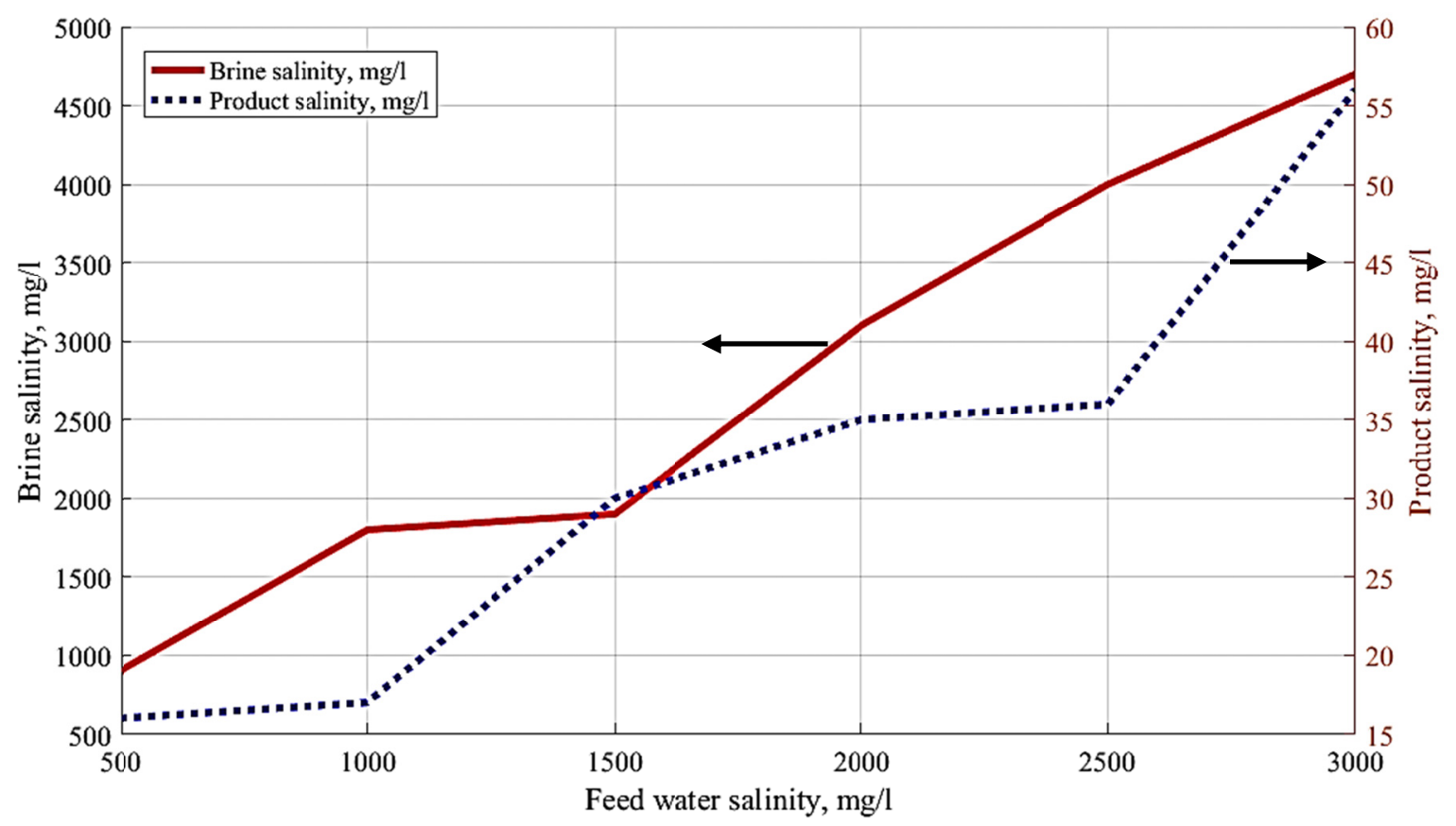

Figure 7 . The effect of feed salinity on the product salinity and brine salinity, mg/l.

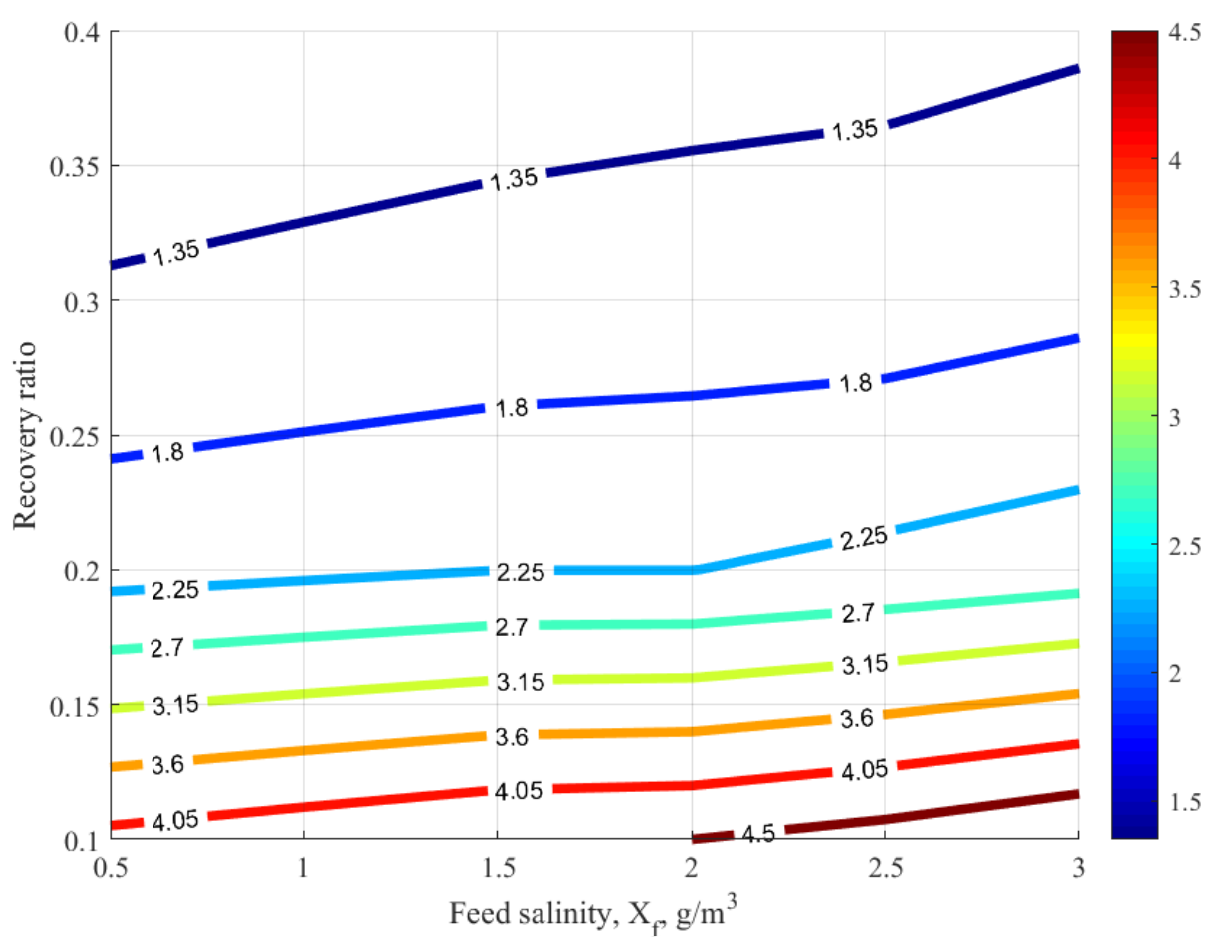

Figure 8 . Feed salinity effect based on the recovery ratio results on the SPC, $\mathrm{kWh} / \mathrm{m}^{3}$. 


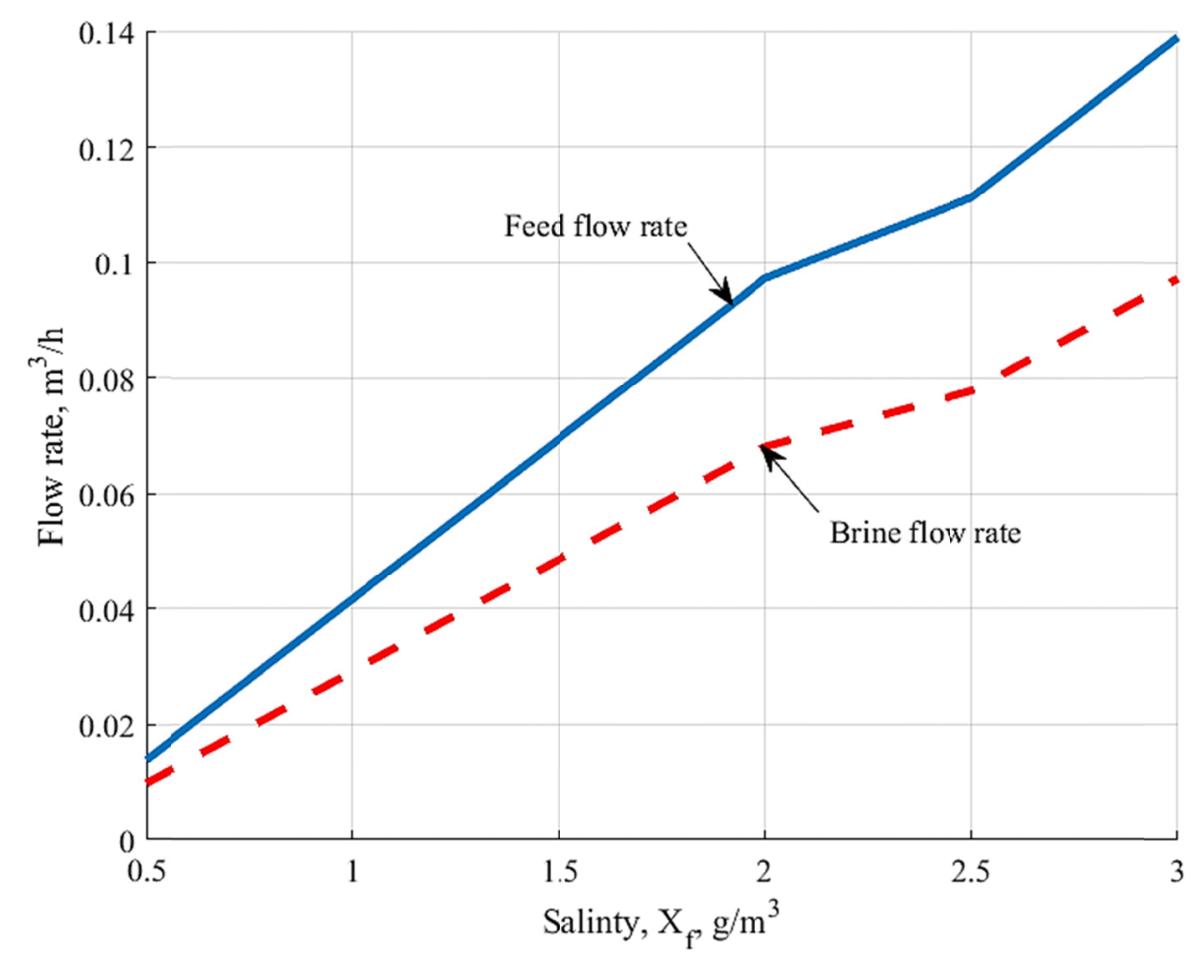

Figure 9. Salinity effect on the feed and brine flow rates.

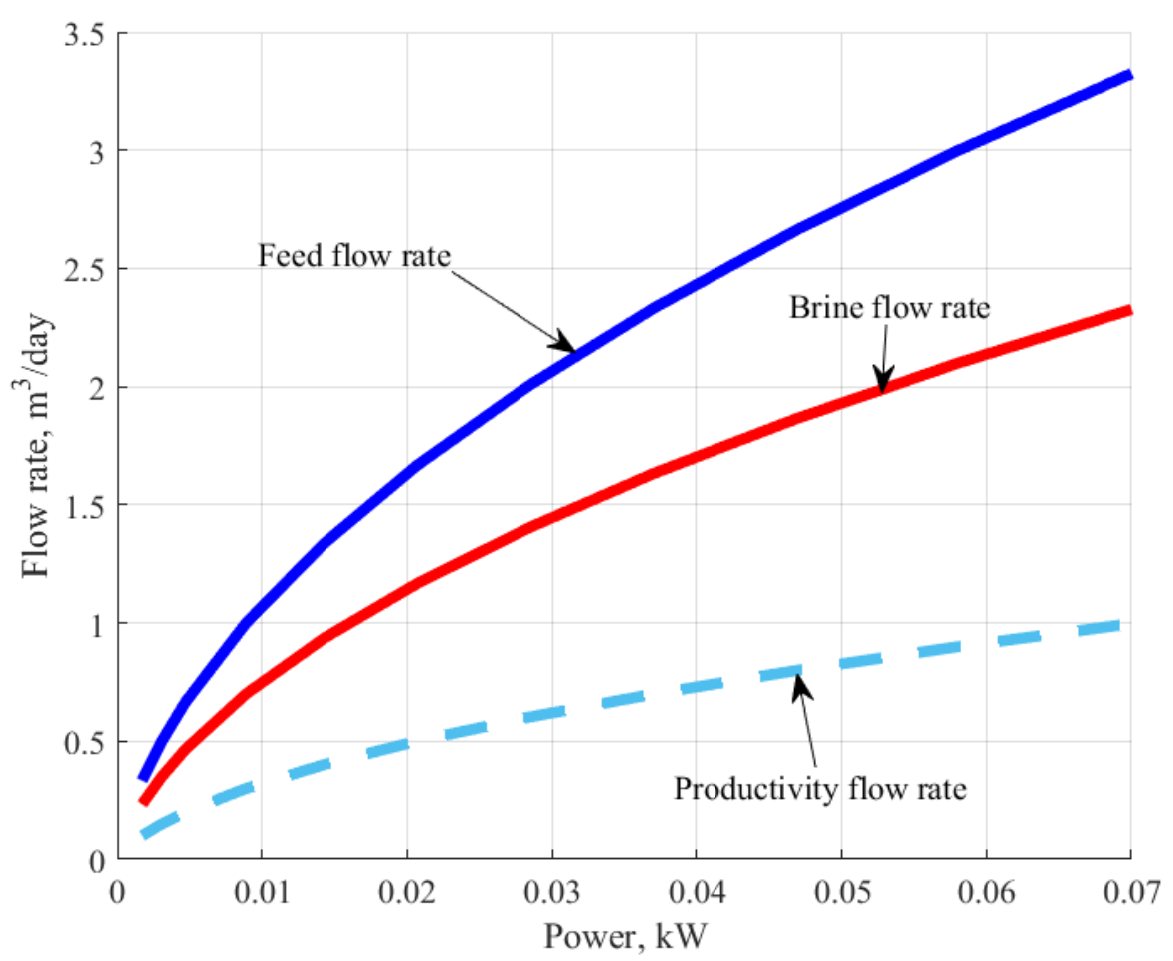

Figure 10. The effect of the developed power on the system flow rates.

\subsection{PV/VWT Performance Results}

The PV performance is measured according to the voltage, current and module power changes with respect to solar radiation along the time domain of the day. Figure 11 shows the performance curves of the PV module according to the change of Is, $\mathrm{W} / \mathrm{m}^{2}$ every hour. The mean value was at $25.3 \mathrm{~V}$ and $2.2 \mathrm{~A}$. At Is $=335 \mathrm{~W} / \mathrm{m}^{2}$, the 
voltage regulates between $10 \mathrm{~V}$ and $35 \mathrm{~V}$ within one hour. However, the current was changed from 2.9 A down to $0.003 \mathrm{~A}$. The curves show that by increasing the Is, the current would increase thence, increasing the generated power from the PV panel. It also shows the effect of the voltage on the PV power. Curve fittings of the voltage, current and system power are modeled in the Appendix. Figure 12 shows the dynamic effect of voltage and current on the module power. More voltage values mean more power generated. The effect of voltage is considered remarkable more the current. Its effect is highly notable as in Figure 12 Based on (G.Papazov, 1996) recommendations, battery life will remain in power development for at least 5 years of operation. Figure 12-a shows the variation of PV voltage with respect to solar radiation and time domain. There was a slightly change with respect to solar radiation. However, the significant change with respect to solar radiation has been noticed in case of PV current (Figure 12-b). It is pin pointed on Figure 12-a that reading level of the voltage was increasing up to 40 45Volt as a maximum value. The current maximum level was recorded between $5 \mathrm{~A}$ and $8 \mathrm{~A}$.

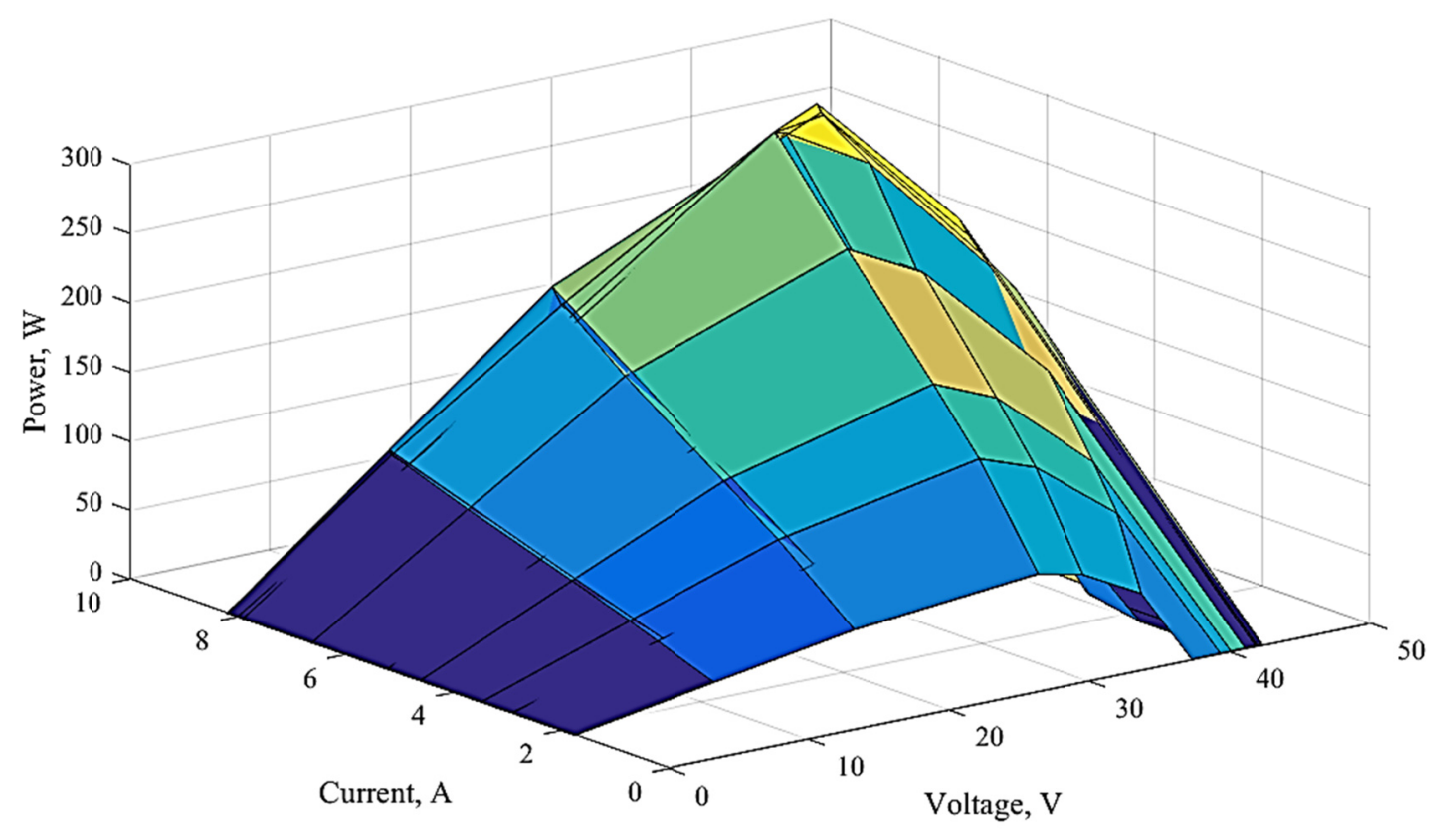

Figure 11. Effect of module voltage and current on the power generation. 

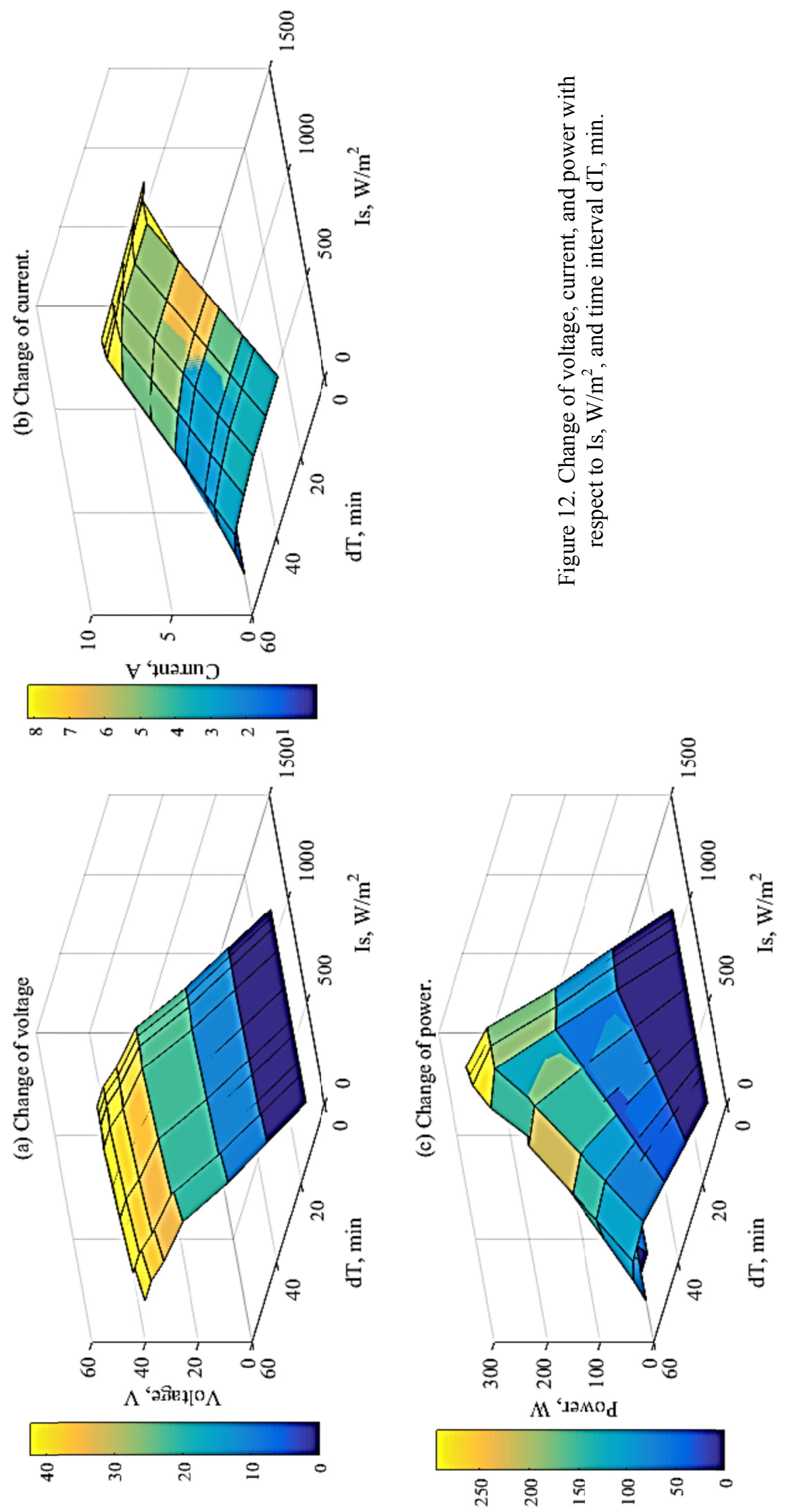
Figure 13 shows the power values that been recorded for the vertical wind turbine unit (VWT). Increasing the wind speed would increase the power generated from the turbine unit. At wind speed with $14 \mathrm{~m} / \mathrm{s}$, the turbine generated about $280 \mathrm{~W}$ of power which is considered quite sufficient as an energy recovery unit suitable for batteries. Figure 14 shows the data results along one year as an example related to the variation of solar radiation, wind speed, and system productivity. Figure 14-a shows the variation of the loads along one year according to PV, VWT and system batteries. It has been noticed that the loads on PV/Batteries was much greater than it had on the VWT. Moreover; the summer time conceded larger effect on loads against the other seasons. The same behavior has been noticed on Figure 14-b related to the system running costs. Summer time shows a great effect with respect to membranes cost. The TWP is reduced in Figure 14-c as a normal reflection to the increase of system productivity during the summer time. The range of water price was recorded as 0.38 to 0.45 . Furthermore, the specific power consumption was noticed higher in summer time by $1.5 \mathrm{kWh} / \mathrm{m}^{3}$. However, it was still in normal values $\left(<2-3.5 \mathrm{kWh} / \mathrm{m}^{3}\right)$ regardless the increase of system productivity during the summer time. Figure 15 shows the data results along a typical day in summer time. Figure 15-a shows the load variation starting from morning along 24 hours. During the absence of solar radiation the VWT unit will recover the system supporting the batteries. Then at the beginning of first light, the PV will begin to charge the batteries and the system will run smoothly at nearly constant range of water production rate $\left(\sim 1 \mathrm{~m}^{3} /\right.$ day $)$. Figure $15-\mathrm{b}$ shows the effect of environmental operating conditions on the effective area of the PV. The area would decrease by the increase of solar radiation. Figure 15-c shows the effect on total water price along one day. The figure shows the actual price of water based on the load variation and the change of environmental operating conditions.

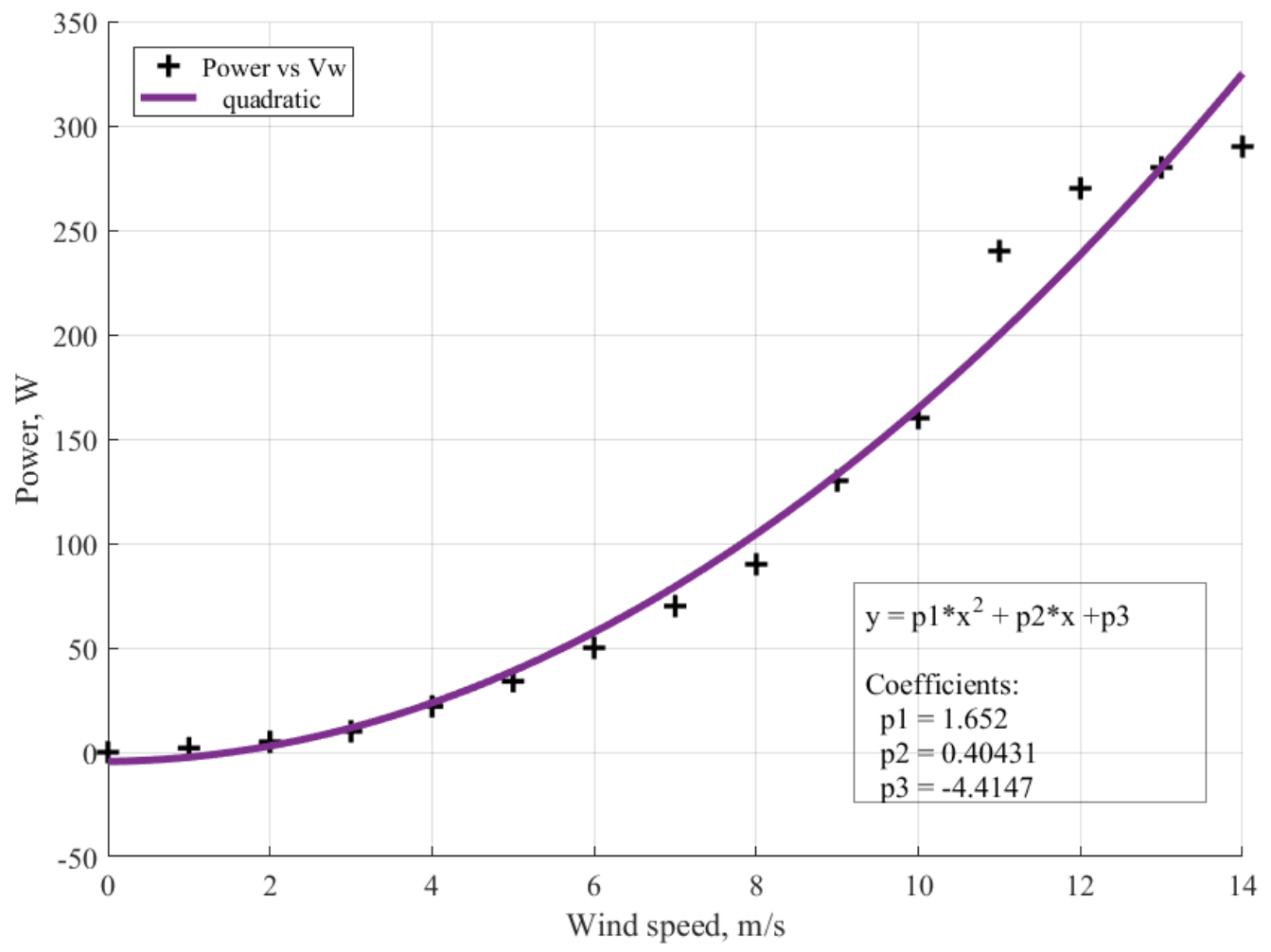

Figure13. The recorded power generation of the proposed VWT unit. 
(a) Loads along one year, $\mathrm{kW}$.

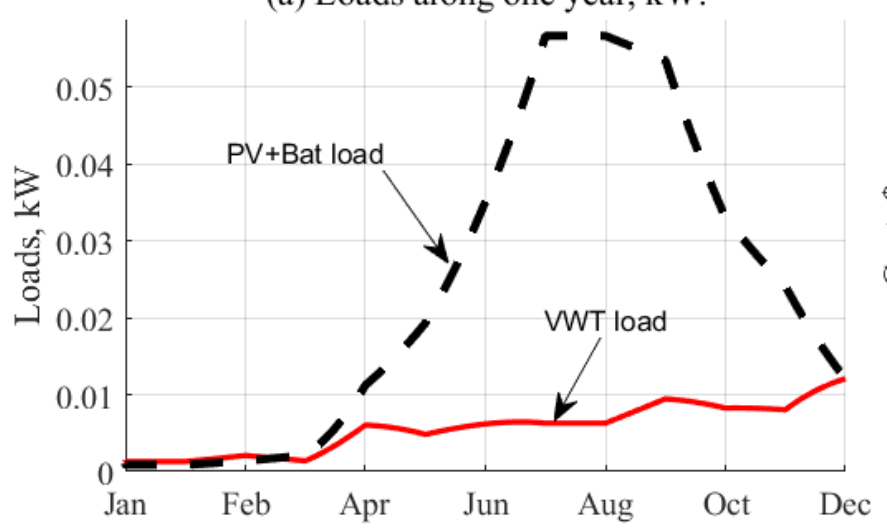

(c) TWP, $\$ / \mathrm{m}^{3}$.

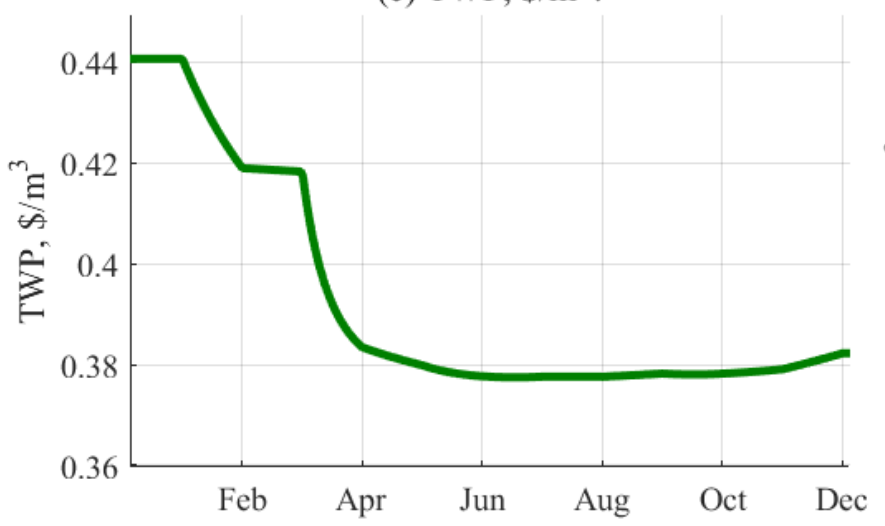

(b) Costs, $\$ / \mathrm{yr}$.

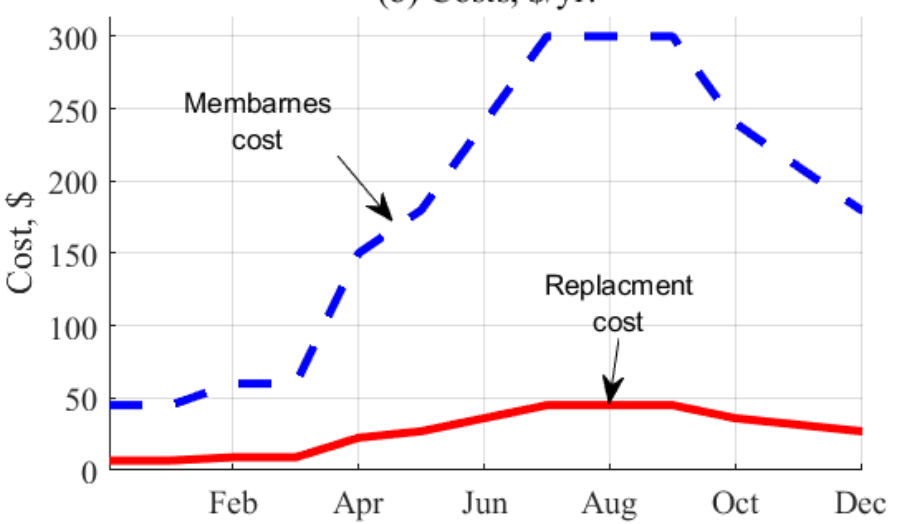

(d) $\mathrm{SPC}, \mathrm{kWh} / \mathrm{m}^{3}$.

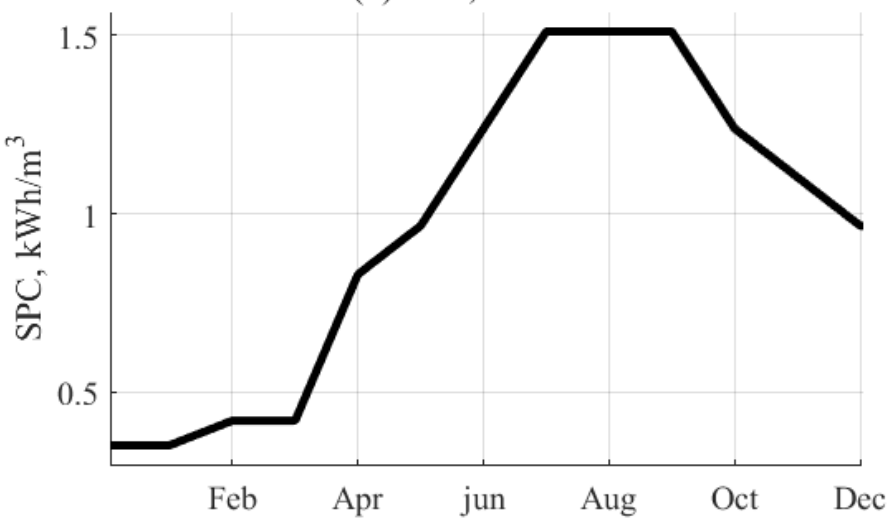

Figure 14. Data results along one year of operation: (a) Loads on PV and VWT, kW, (b) Costs, \$, (c) TWP, $\$ / \mathrm{m}^{3}$, (d) SPC, $\mathrm{kWh} / \mathrm{m}^{3}$. 

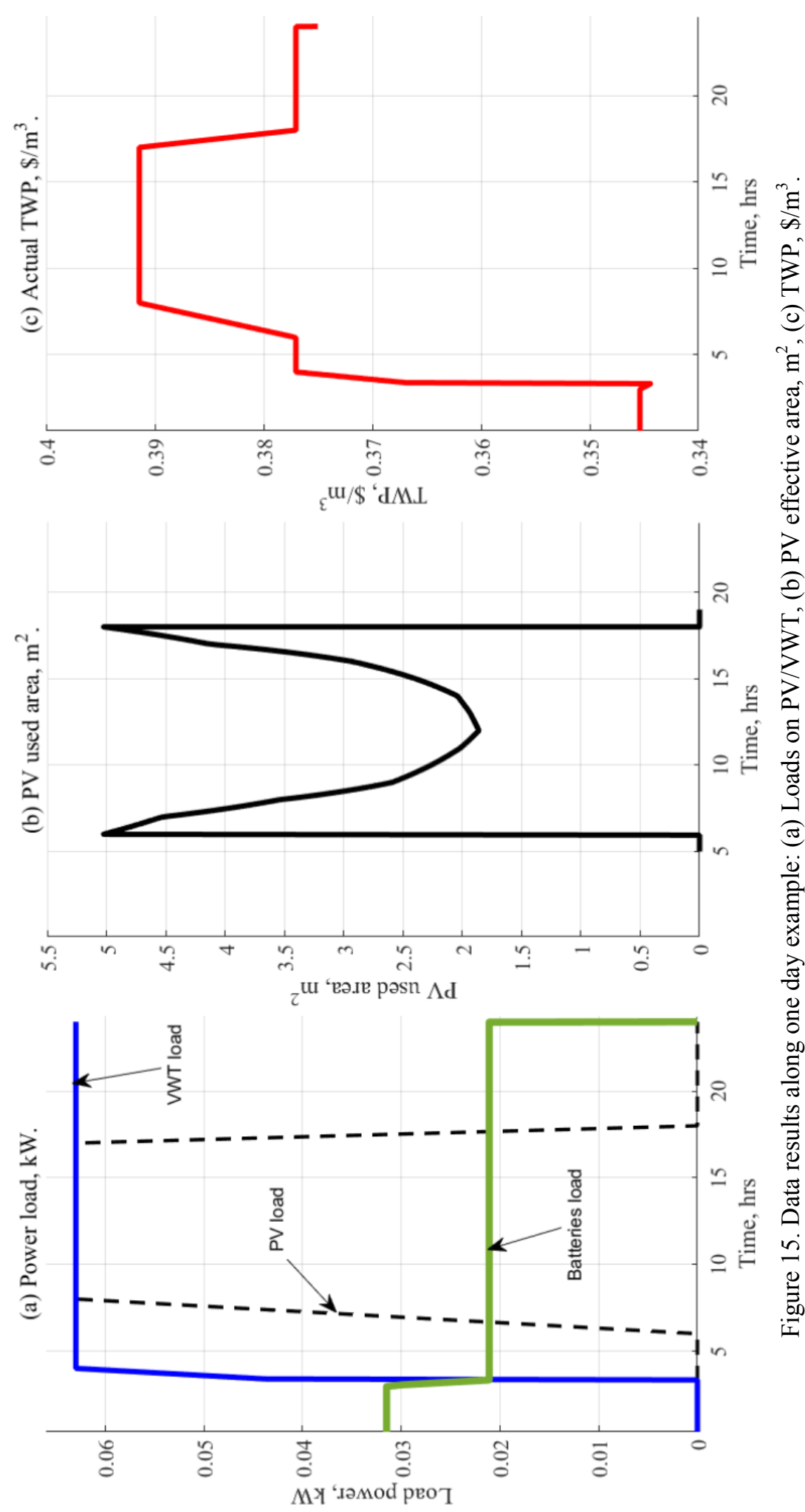

\subsection{Cost Analysis}

Cost analysis are shown in this section based on the initial cost of each purchased unit. The total cost is calculated then the unit product cost will be calculated. Table 3 represents the list of units with costs. For each unit, cost analysis is pin pointed as following: 
$>\mathrm{PV}$ costs, $C_{p v}=2 \times 500 \$$

$>$ Battery costs, $C_{b a t}=2 \times 600 \$$

$>$ Solar control charger, $C_{s c c}=250 \$$

$>$ Inverter cost, $C_{i}=550 \$$

$>$ Wind turbine cost, $C_{V W T}=1100 \$$

$>$ Reverse osmosis unit cost, $C_{R O}=250 \$$

$>$ Mobile unit cost, $C_{M U}=1800 \$$

$>$ Total costs, $C_{\text {total }}=C_{p v}+C_{b a t}+C_{s c c}+C_{i}+C_{V W T}+C_{R O}+C_{M U}=6,150 \$$

Calculate the amortization factor $A_{f}, 1 / \mathrm{yr}$ :

$$
A_{f}=\frac{i .(1+i)^{20}}{(1+i)^{20}-1} \ldots . .
$$

Where, $(i)$ is the interest rate and is fixed at 5\%. Therefore; the amortization factor would equal to 0.0802.

Calculating the annual fixed charges $\$ / y r$ at amortization factor equal to 0.0802 :

$$
A F C=A_{f} \times C_{\text {total }}=6150 \times 0.0802=493.49 \$ / \mathrm{yr}
$$

Calculating the unit product cost $U P C_{t}, \$ / \mathrm{m}^{3}$, at maximum productivity equal to $1 \mathrm{~m}^{3} /$ day and load factor equal to 0.9:

$$
U P C_{t}=\frac{A F C=493.49}{0.9 \times M_{d}=1 \times 365}=\frac{1.51 \$}{m^{3}} \ldots .
$$

Table 3. Cost analysis for all units.

\begin{tabular}{cc}
\hline Unit: & Cost, \$: \\
\hline Photovoltaic modules & 1000 \\
Batteries bank & 1200 \\
Solar control charger device & 250 \\
Inverter device & 550 \\
Vertical wind turbine & 1100 \\
Reverse Osmosis unit & 250 \\
Mobile control unit & 1800 \\
Total costs, \$ & 6150 \\
\hline
\end{tabular}

\section{Conclusion}

This work is subjected to the matter of powering reverse osmosis (RO) desalination system by the use of renewable energy sources such as solar photovoltaic and/or wind energy. The RO found directly combined with PV site and/or VWT unit unlike the solar thermal power type. The novelty of the work is emerged from many sides, (a) system mobility, (b) small scale operation, and (c) the operation of vertical type wind turbine as a recovery unit. The system is constructed in Jouf University, Saudi Arabia under the meteorological operating conditions of Lat: 29.953894, Lng: $\mathbf{4 0 . 1 9 7 0 4 4}$ (desert area). The main goal is to construct a system engineering in order to produce an amount of fresh water in the range of $0.1-1 \mathrm{~m}^{3} /$ day. Saline well water source is used with a salinity range of 500-5000ppm. Two PV modules (300Watts) are used to operate the RO during the day light. Moreover, VWT unit is used to operate the system during the night time and/or working as a recovery system for the batteries. VWT doesn't need any controller for wind catching or any directional system. Batteries bank is used as an energy recovery unit according to the fluctuations of the environmental conditions. The system has many benefits concluded into the following:

Compactness and limited needs for ground area (total system weight $=120 \mathrm{~kg}$ ).

$>\quad$ Low energy requirements. The power wasn't exceeded over $0.03-0.06 \mathrm{~kW}$.

$>\quad$ No need for additional heating components.

$>\quad$ Ease of operation and maintenance.

$>\quad$ Suitability for small capacity of freshwater to meet requirements of small communities. 
$>\quad$ No need for chemical pretreatment equipment.

$>\quad$ So much suitable for desert safari travels.

$>\quad$ Can serve in rural areas and exploratory trips across the desert.

The results reveal that increasing the system productivity would increase the $\mathrm{SPC}, \mathrm{kWh} / \mathrm{m}^{3}$. Moreover, increasing the salinity ratios would also increase the load on the RO membranes. The system unit product cost was around $1.5 \$ / \mathrm{m}^{3}$ putting in considerations the membranes replacement on the long run. The PV-RO and VWT-RO are proven promising technologies to produce a sustainable fresh water putting in mind their positive environmental impacts. The mobile system is easy to be transferred to produce fresh water for remote areas. As a future work, such compact configuration could be widespread and be used for the removing water contaminations and purification processes. Optimization process will take its place in order to adopt a small system for the purpose of water desalination and purification process.

\section{Acknowledgment}

The authors acknowledge the financial support from Jouf University, KSA, under Grant no. 37/390.

\section{References}

A. Lamei, P. van der Zaag \& E. von Münch. (2008). Basic cost equations to estimate unit production costs for RO desalination and long-distance piping to supply water to tourism-dominated arid coastal regions of Egypt. Desalination, 225, 1-12, https://doi.org/10.1016/j.desal.2007.08.003.

A.M. Helal, S.A. Al-Malek. \& E.S. Al-Katheeri. (2008). Economic feasibility of alternative designs of a PV-RO desalination unit for remote areas in the United Arab Emirates. Desalination, 221, 1-16https://doi.org/10.1016/j.desal.2007.01.064

A. Cipollina, E. Tzen, V. Subiela, M. Papapetrou, J. Koschikowski, R. Schwantes, M. Wieghaus \& G. Zaragoza. (2015). Renewable energy desalination: performance analysis and operating data of existing RES desalination plants. Desalination and Water Treatment, 55(11): 3120-3140.

A. Lilane, D. Saifaoui, S. Hariss, H. Jenkal \& M.Chouiekh, (2019). Modeling and simulation of the performances of the reverse osmosis membrane, https://doi.org/10.1016/j.matpr.2019.07.694.

Annamaria, Mazzoni, Essam, Heggy. \& Giovanni, Scabbia.(2018). Forecasting water budget deficits and groundwater depletion in the main fossil aquifer systems in North Africa and the Arabian Peninsula, https://doi.org/10.1016/j.gloenvcha.2018.09.009.

C.C.K. Liu, W. Xia \& J.W. Park. (2007). A wind-driven reverse osmosis system for aquaculture wastewater reuse and nutrient recovery. Desalination, 202, 24-30, https://doi.org/10.1016/j.desal.2005.12.034.

Driss Zejli, Ahmed Ouammi, Roberto Sacile, Hanane Dagdougui \& Azzeddine Elmidaoui, (2011). An optimization model for a mechanical vapor compression desalination plant driven by a wind/PV hybrid system, Applied Energy, 88, 4042-4054 https://doi.org/10.1016/j.apenergy.2011.04.031

D. Manolakos, Essam, Sh. Mohamed, I. Karagiannis \& G. Papadakis. (2008). Technical and economic comparison between PV-RO system and RO-Solar Rankine system. Case study: Thirasia island. Desalination, 22, 137-46, https://doi.org/10.1016/j.desal.2007.01.066.

Djamila, Abdeslame, Dehmas., Nabila, Kherba., Fouad, Boukli. Hacene., Nachida, Kasbadji. Merzouk., Mustapha, Merzouk., Hacene, Mahmoudia. \& Mattheus F.A. Goosen. (2011). On the use of wind energy to power reverse osmosis desalination plant: A case study from Ténès (Algeria). Renewable and Sustainable Energy Reviews, 15, 956-963 https://doi.org/10.1016/j.rser.2010.11.004

E. Tzen, K. Perrakis. \& P. Baltas. (1998). Design of a standalone PV-desalination system for rural areas, Desalination, 119, 327-334, https://doi.org/10.1016/S0011-9164(98)00177-5.

Essam, Sh. Mohamed., G. Papadakis, E. Mathioulakis \& V. Belessiotis. (2008). A direct coupled photovoltaic seawater reverse osmosis desalination system toward battery-based systems-a technical and economical experimental comparative study. Desalination, 221, 17-22https://doi.org/10.1016/j.desal.2007.01.065

Freire-Gormaly, M. \& Bilton, A. (2018) Experimental quantification of the effect of intermittent operation on membrane performance of solar powered reverse osmosis desalination systems, Desalination, 435, 188-197, http://dx.doi.org/10.1016/j.desal.2017.09.013.

Freire-Gormaly, M. \& Bilton, A. (2018) Experimental Characterization of Membrane Fouling under Intermittent Operation and Its Application to the Optimization of Solar Photovoltaic Powered Reverse Osmosis 
Drinking Water Treatment Systems, University of Toronto, $\mathrm{PhD}$ Thesis.

F.M. Mohee \& A. Al-mayah (2017). Effect of modulus of elasticity and thickness of the CFRP plate on the performance of a novel anchor for structural retrofitting and rehabilitation applications, Eng. Struct, 153, 302-316. https://doi.org/10.1016/j.engstruct.2017.09.057

F.M. Mohee, Development (2017). Analysis and Testing of Innovative Mechanical Prestressing Anchors for CFRP Plates for Structural Rehabilitation and Retrofitting, University of Waterloo (UWSpace), ,http://hdl.handle.net/10012/11207.

G.E. Ahmad \& J. Schmid. (2002). Feasibility study of brackish water desalination in the Egyptian deserts and rural regions using PV systems. Energy Conversion and Management, 43, 2641-2649, PII: S01968904(01)00189-3.https://doi.org/10.1016/S0196-8904(01)00189-3

G. Papazov \& D. Pavlov (1996). Influence of cycling current and power profiles on the cycle life of lead/acid batteries, Journal of Power Sources, 62(2), 193-199, https://doi.org/10.1016/S0378-7753(96)02422-6.

George Kyriakarakos, Anastasios I.Dounis, Konstantinos G. Arvanitis \& George Papadakis (2017). Design of a Fuzzy Cognitive Maps variable-load energy management system for autonomous PV-reverse osmosis desalination systems: A simulation survey, Applied Energy, 187(1), 575-584, http://dx.doi.org/10.1016/j.apenergy.2016.11.077.

H. Nouri, B. Stokvis, A. Galindo, M. Blatchford \& A.Y. Hoekstra (2019). Water scarcity alleviation through water footprint reduction in agriculture: The effect of soil mulching and drip irrigation, Science of the Total Environment, 653, 241-252, https://doi.org/10.1016/j.scitotenv.2018.10.311.

Ignacio de la Nuez Pestana, Francisco Javier Garcia Latorre, Celso Argudo Espinoza \& Antonio Gomez Gotor. (2004). Optimization of RO desalination systems powered by renewable energies. Part I: Wind energy. Desalination, 160, 293-299, https://doi.org/10.1016/S0011-9164(04)90031-8.

L. García-Rodríguez, V. Romero-Ternero \& C. Gómez-Camacho. (2001). Economic analysis of wind-powered desalination. Desalination, 137, 259-265, https://doi.org/10.1016/S0011-9164(01)00235-1.

M. Freire-Gormaly \& A.M. Bilton (2017). An experimental system for characterization of membrane fouling of solar photovoltaic reverse osmosis systems under intermittent operation, Desalination and Water Treatment, https://doi.org/10.5004/dwt.2017.20391

Mohamed A. Sharaf Eldean \& A.M. Soliman (2013). A new visual library for modeling and simulation of renewable energy desalination systems (REDS), Desalination and Water Treatment, 1-16,

Mohammed Laissaoui, Patricia Palenzuela, Mohamed A. Sharaf Eldean, Diego-César Alacron-Padilla \& Driss Nehari (2018). Techno-economic analysis of a stand-alone solar desalination plant at variable load conditions, Applied Thermal Engineering, 133, 659-670, https://doi.org/10.1016/j.applthermaleng.2018.01.074.

Mohee, F.M., Al-Mayah, A. \& Plumtree, A. (2017). Development of a novel prestressing anchor for CFRP plates: Experimental investigations. Composite Structures, 176, 20-32. Available at: http://dx.doi.org/10.1016/j.compstruct.2017.05.011.

Nafey AS \& Sharaf MA. (2010). Combined solar organic Rankine cycle with reverse osmosis desalination process: Energy, exergy, and cost evaluations. Renewable Energy, 35, 2571-2580, https://doi.org/10.1016/j.renene.2010.03.034

Upeksha Caldera, Dmitrii Bogdanov \& Christian Breyer (2016). Local cost of seawater RO desalination based on solar PV and wind energy: A global estimate. Desalination, 385, 207-216, http://dx.doi.org/10.1016/j.desal.2016.02.004.

V. Romero-Ternero, L. García-Rodríguez \& C. Gómez-Camacho. (2005). Thermoeconomic analysis of wind powered seawater reverse osmosis desalination in the Canary Islands. Desalination, 186, 291-298, https://doi.org/10.1016/j.desal.2005.06.006.

Wilf Mark \& Bartels Craig, (2005). Optimization of seawater RO systems design, Desalination, (173), 1-12https://doi.org/10.1016/j.desal.2004.06.206 


\section{The Appendix: PV performance correlations}

\section{A.1 Voltage:}

Linear model Poly23: $\mathrm{x}=\mathrm{Is}, \mathrm{y}=\mathrm{dT}$

$$
\begin{gathered}
\mathrm{f}(\mathrm{x}, \mathrm{y})=\mathrm{p} 00+\mathrm{p} 10^{*} \mathrm{x}+\mathrm{p} 01^{*} \mathrm{y}+\mathrm{p} 20^{*} \mathrm{x}^{\wedge} 2+\mathrm{p} 11^{*} \mathrm{x}^{*} \mathrm{y}+\mathrm{p} 02^{*} \mathrm{y}^{\wedge} 2+\mathrm{p} 21^{*} \mathrm{x}^{\wedge} 2^{*} \mathrm{y}+ \\
\mathrm{p} 12^{*} \mathrm{x}^{*} \mathrm{y}^{\wedge} 2+\mathrm{p} 03^{*} \mathrm{y}^{\wedge} 3
\end{gathered}
$$

Coefficients (with $95 \%$ confidence bounds):

$$
\begin{array}{lr}
\text { p00 } & =-6.895(-12.32,-1.47) \\
\text { p10 } & -0.0027(-0.01637,0.01097) \\
\text { p01 } & 0.4221(0.04713,0.7971) \\
\text { p20 } & =4.782 \mathrm{e}-07(-8.817 \mathrm{e}-06,9.773 \mathrm{e}-06) \\
\text { p11 } & =0.0003865(-2.896 \mathrm{e}-05,0.0008019) \\
\text { p02 } & 0.02686(0.01674,0.03697) \\
\text { p21 } & =-1.282 \mathrm{e}-07(-3.516 \mathrm{e}-07,9.512 \mathrm{e}-08) \\
\text { p12 } & =-1.732 \mathrm{e}-06(-5.524 \mathrm{e}-06,2.061 \mathrm{e}-06) \\
\text { p03 } & -0.0003734(-0.0004656,-0.0002811)
\end{array}
$$

Goodness of fit:

SSE: 108.5

R-square: 0.9938

Adjusted R-square: 0.9931

RMSE: 1.263

\section{A.2 Current:}

Linear model Poly13: $\mathrm{x}=\mathrm{Is}, \mathrm{y}=\mathrm{dT}$

$$
f(x, y)=p 00+p 10 * x+p 01 * y+p 11 * x * y+p 02 * y^{\wedge} 2+p 12 * x * y^{\wedge} 2+p 03 * y^{\wedge} 3
$$

Coefficients (with $95 \%$ confidence bounds):

$$
\begin{array}{lc}
\text { p00 } & =6.398(4.089,8.707) \\
\text { p10 } & 0.003908(0.001545,0.006272) \\
\text { p01 }= & -0.7002(-0.9061,-0.4943) \\
\text { p11 }= & 0.0002862(0.0001318,0.0004405) \\
\text { p02 }= & 0.0233(0.01759,0.029) \\
\text { p12 }=-5.309 \mathrm{e}-06(-7.447 \mathrm{e}-06,-3.17 \mathrm{e}-06) \\
\text { p03 }=-0.0002281(-0.0002801,-0.0001761)
\end{array}
$$

Goodness of fit:

SSE: 35.56

R-square: 0.9418

Adjusted R-square: 0.9368

RMSE: 0.7127

\section{A.3 Power:}

Linear model Poly23: $x=I s, y=d T$

$$
\begin{gathered}
\mathrm{f}(\mathrm{x}, \mathrm{y})=\mathrm{p} 00+\mathrm{p} 10 * \mathrm{x}+\mathrm{p} 01 * \mathrm{y}+\mathrm{p} 20 * \mathrm{x}^{\wedge} 2+\mathrm{p} 11 * \mathrm{x} * \mathrm{y}+\mathrm{p} 02 * \mathrm{y}^{\wedge} 2+\mathrm{p} 21 * \mathrm{x}^{\wedge} 2 * \mathrm{y}+ \\
\mathrm{p} 12 * \mathrm{x}^{*} \mathrm{y}^{\wedge} 2+\mathrm{p} 03 * \mathrm{y}^{\wedge} 3
\end{gathered}
$$

Coefficients (with $95 \%$ confidence bounds): 


$$
\begin{array}{lc}
\text { p00 } & =214.6(60.98,368.2) \\
\text { p10 } & -0.1451(-0.532,0.2419) \\
\text { p01 } & -30.23(-40.85,-19.61) \\
\text { p20 } & -9.131 \mathrm{e}-05(-0.0003545,0.0001719) \\
\text { p11 }= & 0.02421(0.01245,0.03597) \\
\text { p02 }= & 1.032(0.7455,1.318) \\
\text { p21 }= & 1.775 \mathrm{e}-06(-4.55 \mathrm{e}-06,8.099 \mathrm{e}-06) \\
\text { p12 }=-0.0003471(-0.0004545,-0.0002397) \\
\text { p03 }= & -0.01002(-0.01263,-0.007409)
\end{array}
$$

Goodness of fit:

SSE: $8.699 \mathrm{e}+04$

R-square: 0.8786

Adjusted R-square: 0.8643

RMSE: 35.77

\section{Copyrights}

Copyright for this article is retained by the author(s), with first publication rights granted to the journal.

This is an open-access article distributed under the terms and conditions of the Creative Commons Attribution license (http://creativecommons.org/licenses/by/4.0/). 